\title{
Analysis of New Artifact Collections from Archaic to Ancestral Caddo Sites in the Saline Creek Basin in Northern Smith County, Texas
}

Timothy K. Perttula

Heritage Research Center, Stephen F. Austin State University

Mark Thacker

Follow this and additional works at: https://scholarworks.sfasu.edu/ita

Part of the American Material Culture Commons, Archaeological Anthropology Commons, Environmental Studies Commons, Other American Studies Commons, Other Arts and Humanities Commons, Other History of Art, Architecture, and Archaeology Commons, and the United States History Commons

Tell us how this article helped you.

This Article is brought to you for free and open access by the Center for Regional Heritage Research at SFA ScholarWorks. It has been accepted for inclusion in Index of Texas Archaeology: Open Access Gray Literature from the Lone Star State by an authorized editor of SFA ScholarWorks. For more information, please contact cdsscholarworks@sfasu.edu. 
Analysis of New Artifact Collections from Archaic to Ancestral Caddo Sites in the Saline Creek Basin in Northern Smith County, Texas

\section{Creative Commons License}

(c) (i) (8)

This work is licensed under a Creative Commons Attribution-NonCommercial 4.0 International License 


\title{
Analysis of New Artifact Collections from Archaic to Ancestral Caddo Sites in the Saline Creek Basin in Northern Smith County, Texas
}

\author{
Timothy K. Perttula and Mark Thacker
}

\section{INTRODUCTION}

This article concerns the continued documentation of prehistoric and/or historic artifacts from four sites in the Saline Creek drainage basin in the Post Oak Savannah in northern Smith County, Texas (Diggs et al. 2006:Figures 1-3). Perttula and Walters (2012) discussed an earlier analysis of a set of collections from these same sites. Saline Creek is a northward-flowing tributary to the Sabine River. The sites are ca. $10 \mathrm{~km}$ south of the confluence of Saline Creek with the Sabine River (Figure 1). Saline Creek enters into the Sabine River about $6 \mathrm{~km}$ east (downstream) of the confluence of another major tributary, Lake Fork Creek, with the river.

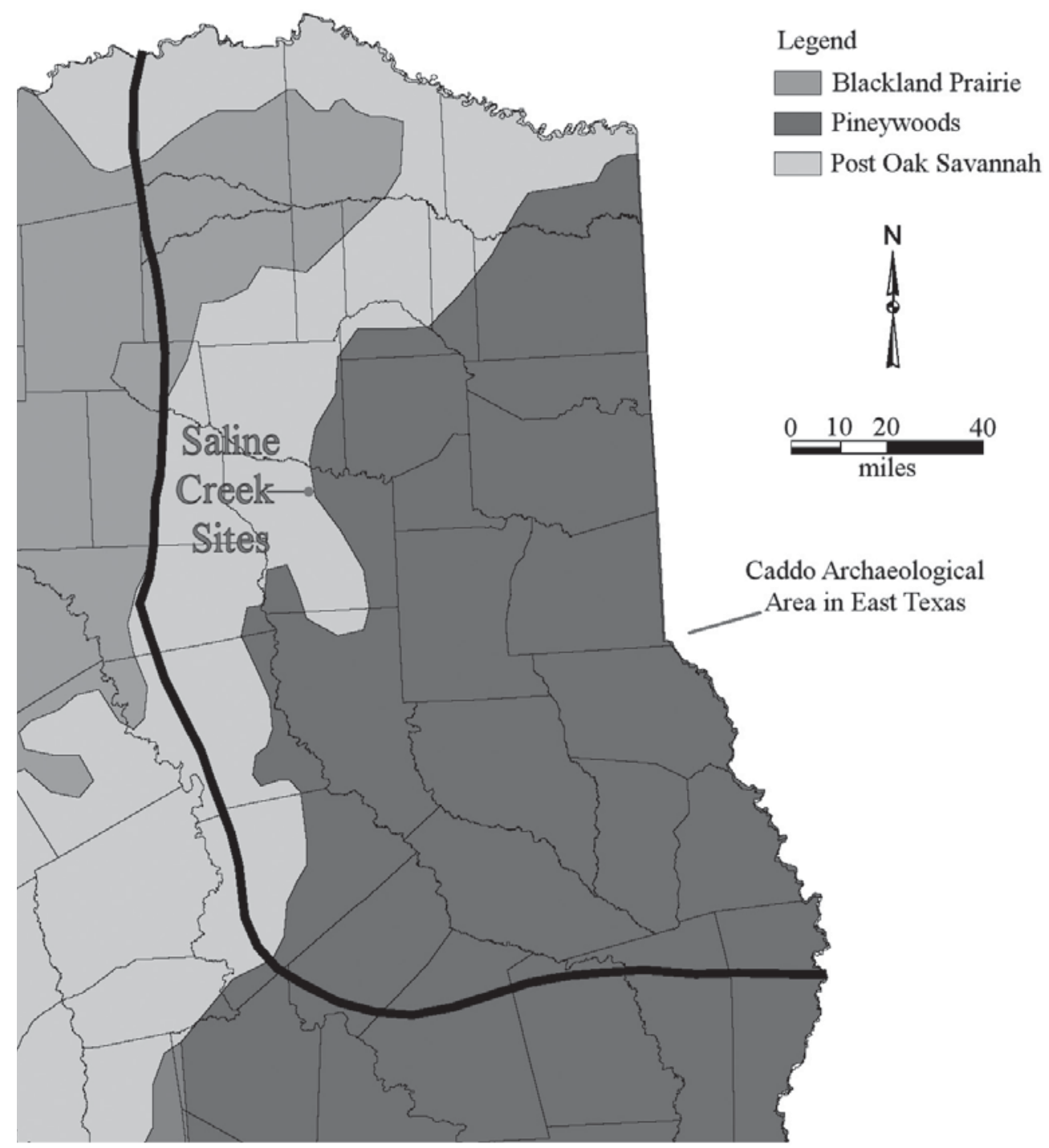

Figure 1. General location of the Saline Creek basin sites in East Texas. 


\section{Sarah's Deer Stand (41SM440)}

The Sarah's Deer Stand site is located on a sandy (Gallime fine sandy loam, 1-5\% slopes, Hatherly 1993) upland ridge that slopes to the west towards Saline Creek, the current channel of which is $540 \mathrm{~m}$ to the west. When the site was recorded in 2010, it had small hardwoods, brush, and a weedy understory; surface visibility was $5 \%$. It has been estimated to cover a $2500 \mathrm{~m}^{2}$ area $(0.62$ acres $)$. There is one area of the site that has crepe myrtle bushes and a charcoal-stained area; these both probably are associated with a mid- $19^{\text {th }}$ to early $20^{\text {th }}$ century component (see below).

There are 275 ancestral Caddo sherds in the collections from the Sarah's Deer Stand site, 69 (25\%) of which have decorations. The plain to decorated sherd ratio is 2.99 . The assemblage is from sherds that are primarily tempered only with grog $(85 \%)$, although some sherds also have bone (13.8\%) and hematite $(1.1 \%)$ inclusions. Detailed analysis of a small sample of the sherds (see Perttula and Walters 2012:Table 1) indicate that $21 \%$ of the sherds are from vessels fired in a high oxygen or oxidizing environment, and another $35.7 \%$ are from vessels incompletely oxidized during firing. The remainder of the sherds $(42.9 \%)$ are from vessels fired in a low oxygen or reducing environment; half of these sherds are from vessels that were also cooled in a reducing environment, and the other half were from vessels that were cooled in the open air, leaving a thin oxidized surface and core on either one or both vessel surfaces.

The sherds from the site are well-preserved, as is indicated by the fact that $57 \%$ of them have evidence of surface treatment (smoothing) on either one or both vessel surfaces (see Perttula and Walters 2012:Table 1). Vessels were medium to large in size, based on the mean body wall thickness of $8.05 \pm 0.95 \mathrm{~mm}$ (range 6.2-10.7 mm), many of them probably used for cooking and storage.

The 69 decorated sherds are predominantly from utility ware vessels $(91.3 \%)$, with only six fine ware sherds (8.7\% of the decorated sherds) (Figure 2a-f). Almost $41 \%$ of the decorated sherds and $44 \%$ of the utility wares have brushed body decorations, either parallel or vertical $(n=26)$ or overlapping $(n=2)$ brushed marks. Two parallel brushed body sherds, possibly from Bullard Brushed jars (see Suhm and Jelks 1962:Plate 11) have tool punctations pushed through the brushing marks.

Twenty-three (33\%) of the decorated sherds have incised lines as the decorative method, with either parallel or straight line $(n=14)$, opposed line $(n=3)$, a horizontal line on a rim (see Figure $2 b, n=1)$, crosshatched lines $(n=3)$, and diagonal/diagonal opposed $(n=2)$ incised elements. Five sherds $(7.2 \%$ of the decorated sherds), including a rim, have rows of tool punctations either on the rim and/or the body of jars (see Figure 2f), and two other body sherds have fingernail punctations. One rim has diagonal opposed incised lines and a triangular zone filled with tool punctations (see Figure 2d), probably from a Maydelle Incised jar. There is a bone-tempered body sherd with a straight appliqued ridge and an adjacent incised line. The remaining utility ware sherd has pinched rows; this may be from a Killough Pinched jar (Suhm and Jelks 1962:Plate 46).

Three of the fine ware body sherds have curvilinear engraved lines, while a fourth, from a bottle, has an engraved circle within a circle surrounded by a curvilinear arc of fine engraved lines (see Perttula and Walters 2012:Figure 1a). The use of a curvilinear arc of engraved lines on this sherd is similar to other examples of Poynor Engraved, possibly including Poynor Engraved, var. Lang (Perttula 2011:Figure 6-64f-g), although this style is most commonly seen on carinated bowls rather than bottles. Other fine ware sherds have either parallel or opposed engraved lines, and there is a bottle neck sherd with a fine engraved line under the lip (see Figure 2c).

The chipped stone artifacts from the Sarah's Deer Stand site include 28 tools or tool fragments, 84 pieces of lithic debris, and four cores. The lithic artifacts indicate that the site was first used by aboriginal peoples during the Late Archaic (ca. 5000-2500 years ago), as marked by several Yarbrough dart points and other expanding or straight stem forms (Figure 3), as well as a ferruginous sandstone gouge (Figure 4, right). Most 


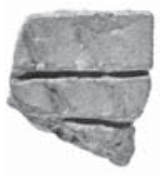

a

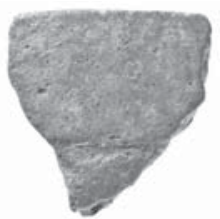

b

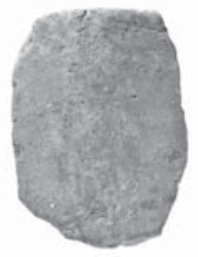

C

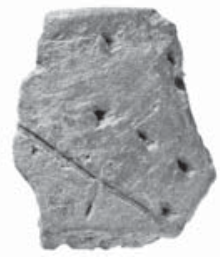

d

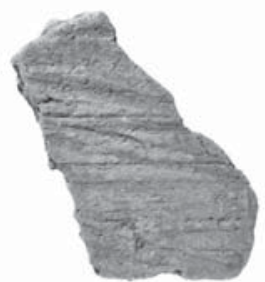

e

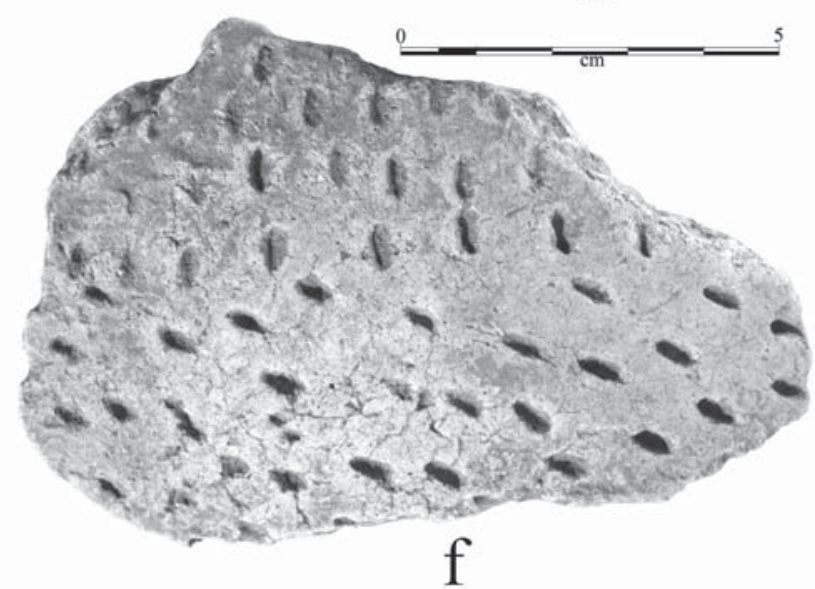

Figure 2. Decorated sherds from the Sarah's Deer Stand site: a-b, incised; c, engraved; d, incised-punctated; e, brushed; f, punctated.

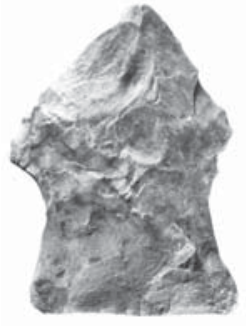

a

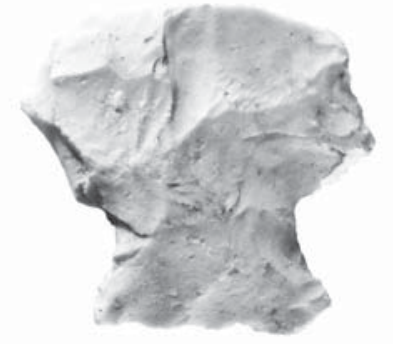

b

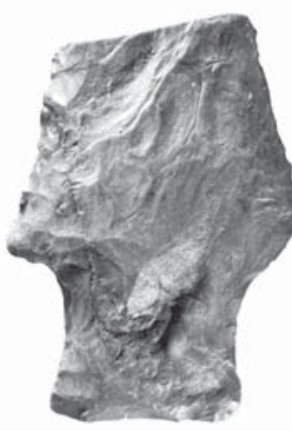

c

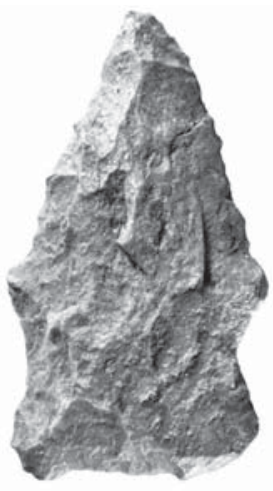

d

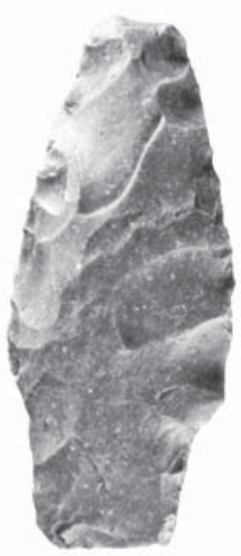

e

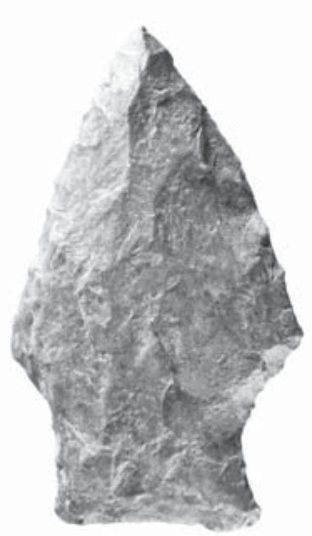

$\mathrm{f}$

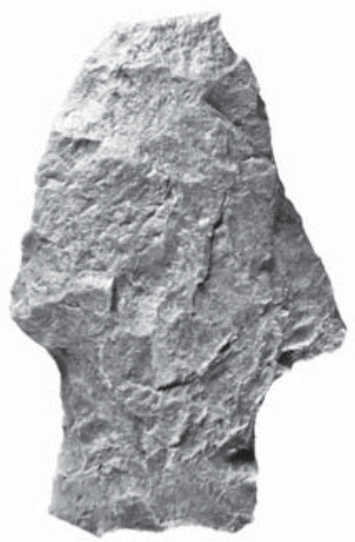

$\mathrm{g}$

Figure 3. Late Archaic dart point forms from the Sarah's Deer Stand site: a-b, f, Edgewood; c, g, Yarbrough; $\mathrm{d}$, Trinity; e, unidentified parallel-stemmed dart point. 


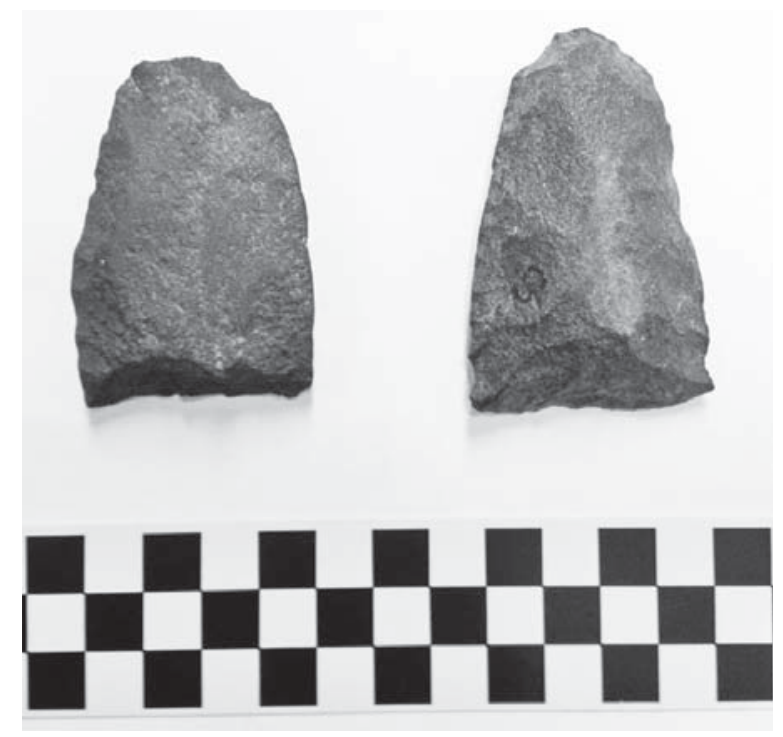

Figure 4. Ferruginous sandstone gouges from the Sarah's Deer Stand (right) and Alligator Pond (left) sites. of the Late Archaic dart points are made from a local heat-treated quartzite, but one Edgewood point is on a white chert, and a parallel stemmed form is made from a dark gray chert (Figure 3e). Other tools that may be associated with this Late Archaic occupation include a quartzite gouge with a unifacial bit, a quartzite bifacial tool fragment, two dart point blade fragments, and a quartzite unifacial tool fragment. The mean stem width of the eight Gary points from the site $(13.02 \mathrm{~mm})$ suggests these are Gary, var. Camden points from a more intensive occupation during the latter part of the Woodland period (ca. A.D. 200-700). More than $84 \%$ of the dart points are made from local coarse-grained or fine-grained quartzite, with others made from a non-local dark gray chert and a Ouachita Mountains orange novaculite.

Three arrow points from the Sarah's Deer Stand site are pre-A.D. 1300 Alba forms (Figure 5a-c); two are made from quartzite, and one is made from a light gray chert. Another arrow point is a well-made Scallorn made from quartzite (Figure 5d). Two other points are of unidentified types because they are broken across the stem (Figure 5e-f). There are also seven arrow point fragments from stemmed arrow points of undetermined type; $71 \%$ are made from local quartzite, one is made from a light grayish-brown chert, and another is made from a gray novaculite. The arrow point preform is also associated with the prehistoric Caddo component recognized in the ceramic sherds, and its presence does mean that arrow points were actually made on site during some period of Caddo use.

The lithic debris from the site is primarily from locally available raw materials, especially a coarsegrained quartzite that had to be heat-treated before it could be successfully reduced and knapped. Nevertheless, non-local lithic debris (probably from Red River gravels or source areas in the Ouachita Mountains, well north of the site) accounts for $27 \%$ of the lithic debris sample. Furthermore, $25 \%$ of the cores are on non-local raw material, and $7.7 \%$ of the chipped stone tools are on non-local lithic raw materials.

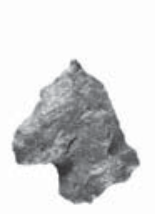

a

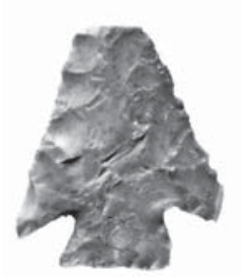

d

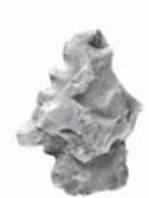

$\mathrm{b}$

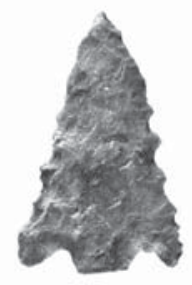

$\mathrm{e}$
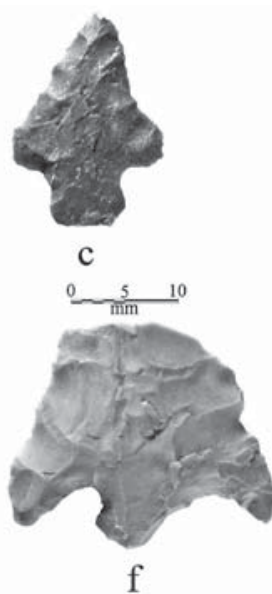

Figure 5. Stemmed arrow points from the Sarah's Deer Stand site: a-c, Alba; d, Scallorn; e, unidentified contracting stem form; f, unidentified expanding stem form.
In addition to the chipped stone artifacts, there are six ground stone tools in the site collection. These are a ferruginous sandstone metate and mano, used in the past for grinding maize and seeds, a bi-pitted stone of ferruginous sandstone, a quartzite mano, as well as two fragments of polished igneous rock from the Ouachita Mountains, probably both celt fragments. Three quartzite fire-cracked rocks suggest that a modicum of hot rock cooking of plant foods (especially roots) took place at the site during one of the occupations).

There is also an historic archaeological component at the site, although its extent and character are unknown. The earliest (ca. 1830s-1860s) part of the occupation, probably by the first settler in this particular locale, is marked by a chert blade gunflint (for a rifle or musket), a short-stemmed molded elbow 
pipe (Figure 6), and nine blue transfer-printed whiteware sherds with floral motifs from plates and cups (Figure 7a-g). The latter were made from ca. 1830s-1860 (Samford 2000).

The later historic use of the site dates after ca. 1890 to as perhaps as late as ca. 1920 . There is a wide variety of artifacts associated with this latter occupation, including wire nails $(\mathrm{n}=3$, produced after 1890), fruit jar zinc lid liner fragments $(n=3)$, a porcelain doll leg, china and iron buttons $(\mathrm{n}=6)-$ including overall buttons with "MOGUL BRAND" and "ENGINEER MAKE" marks (Figure 8a-c) and various plain ceramic sherds and milk glass (from cosmetics jars). These comprise: porcelain $(n=2)$, ironstone $(n=4)$, whiteware $(n=76)$, and

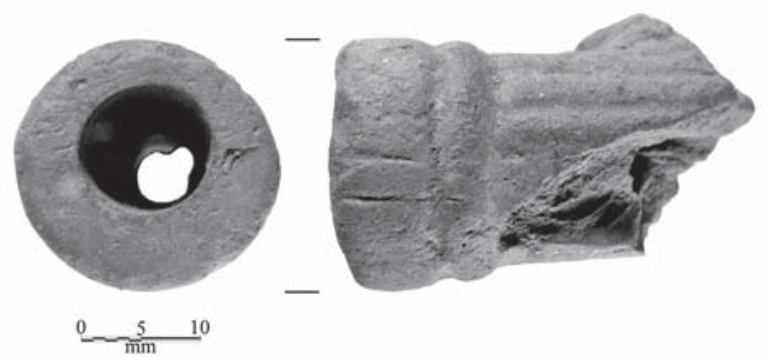

Figure 6. $19^{\text {th }}$ Century Molded elbow pipe from the Sarah's Deer Stand site.

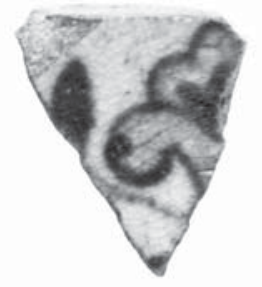

a

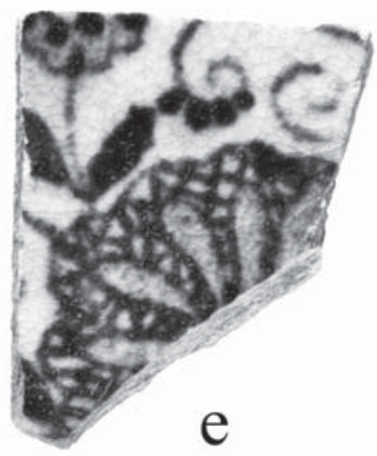

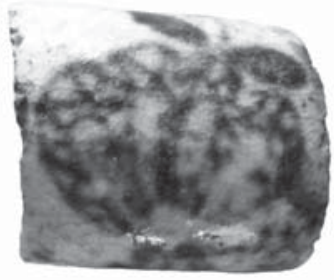

b

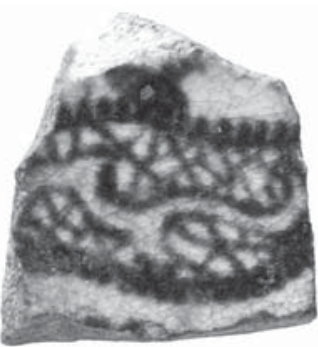

C

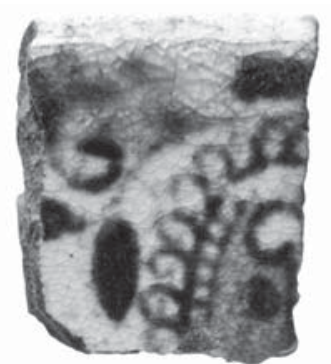

d
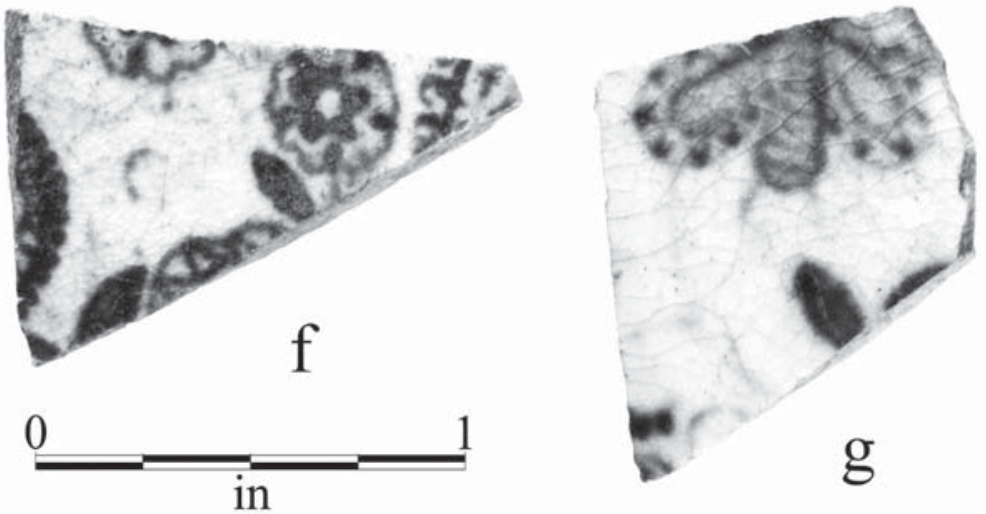

Figure 7. Blue transfer-printed whiteware sherds from the Sarah's Deer Stand site.

stoneware $(\mathrm{n}=27)$. One whiteware rim has a floral embossed decoration on the rim, which is a late $19^{\text {th }}$-early $20^{\text {th }}$ century decorative style, while a base sherd has a partial green crown back mark. The stoneware sherds are represented by Bristol glaze $(n=7)$, salt glaze $(n=7)$, and brown and dark brown lead glaze $(n=13)$; these are stonewares typically found on East Texas farmsteads dating after the mid- $19^{\text {th }}$ century to the early $20^{\text {th }}$ century (Figure 9a-e). Several of the Bristol glaze and salt glaze stoneware sherds have a brown lead glaze on their interior vessel surface.

Bottle glass, snuff jar glass (Figure 10b), and fruit jar glass sherds are abundant at Sarah's Deer Stand site. There are sherds of brown $(n=36)$, aqua $(n=45)$, clear $(n=23)$, and amethyst $(n=23)$ bottle glass. Two of the aqua bottle glass are from late $19^{\text {th }}$ century embossed panel bottles (one with ...ENT $30 \ldots$ embossed on it, Figure 10a), and clear and amethyst bottle lip sherds are from pre-1903 bottles without machine-made seams (Figure 10c-d). There are three aqua fruit jar sherds. 


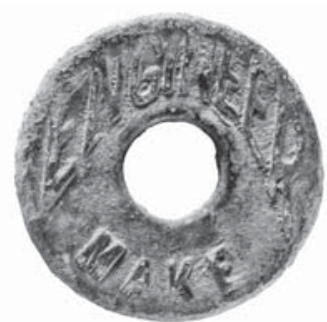

a

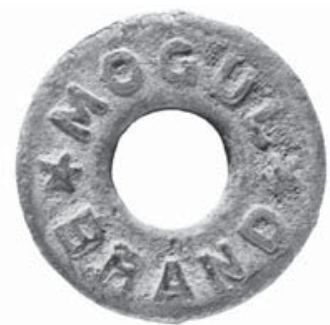

b

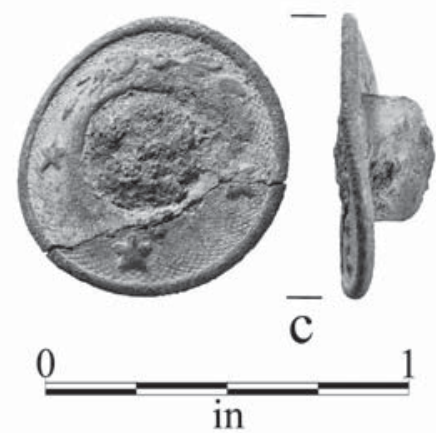

Figure 8. iron buttons from the Sarah's Deer Stand site: $a-b$, overall buttons; $c$, iron button with star decoration.
There are five pieces of aqua window glass in the collection. Their mean thickness $(2.48 \mathrm{~mm})$ suggests they are from panes manufactured in ca. 1921. Finally, there are 13 pieces of animal bone (including teeth) and three pieces of daub.

\section{Handicap Deer Stand (41SM441)}

This site is located on a sandy upland ridge that slopes towards Saline Creek, about $500 \mathrm{~m}$ to the west. The landform has Cuthbert fine sandy loam soils. The site itself had a few hardwood trees, brush, and weeds, and a ground surface visibility of 5\%. The Handicap Deer Stand site is estimated to cover $2400 \mathrm{~m}^{2}(0.6$ acres) in size.

The second collection of Caddo ceramic sherds from the site includes 28 plain rim, body, and base sherds and eight decorated rim and body sherds. With both collections, there is now a total of 83 sherds from Caddo ceramic wares at the Handicap Deer Stand site: 60 plain rim, body and base sherds and 23 decorated rim and body sherds. The plain to decorated sherd ratio is 2.61 .

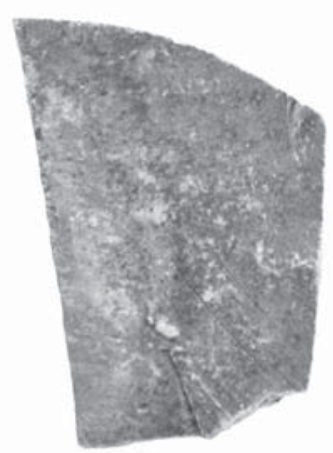

a

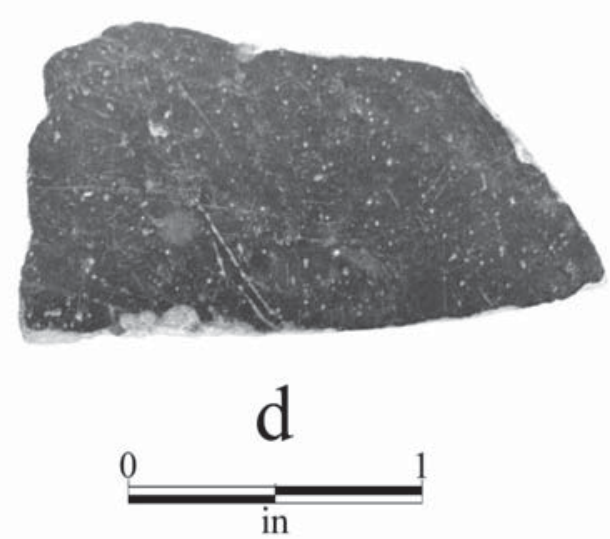

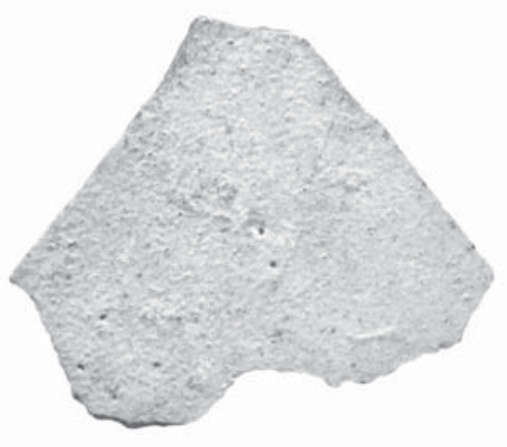

$\mathrm{C}$

b

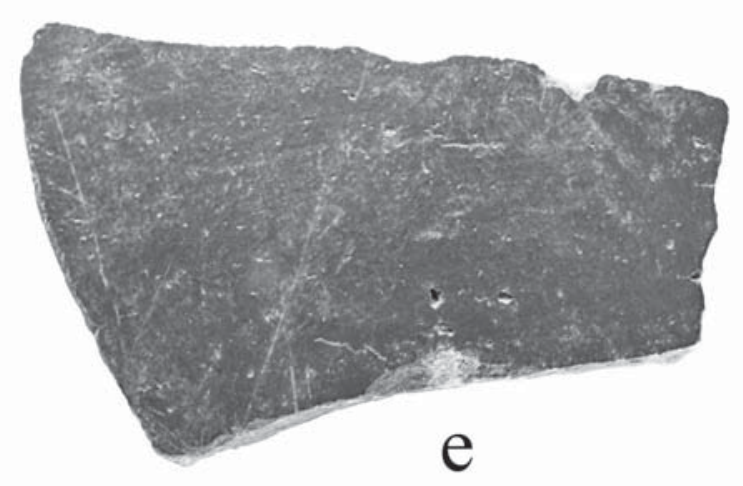

Figure 9. Stoneware sherds from the Sarah's Deer Stand site: a-c, salt glaze; d-e, lead glaze. 


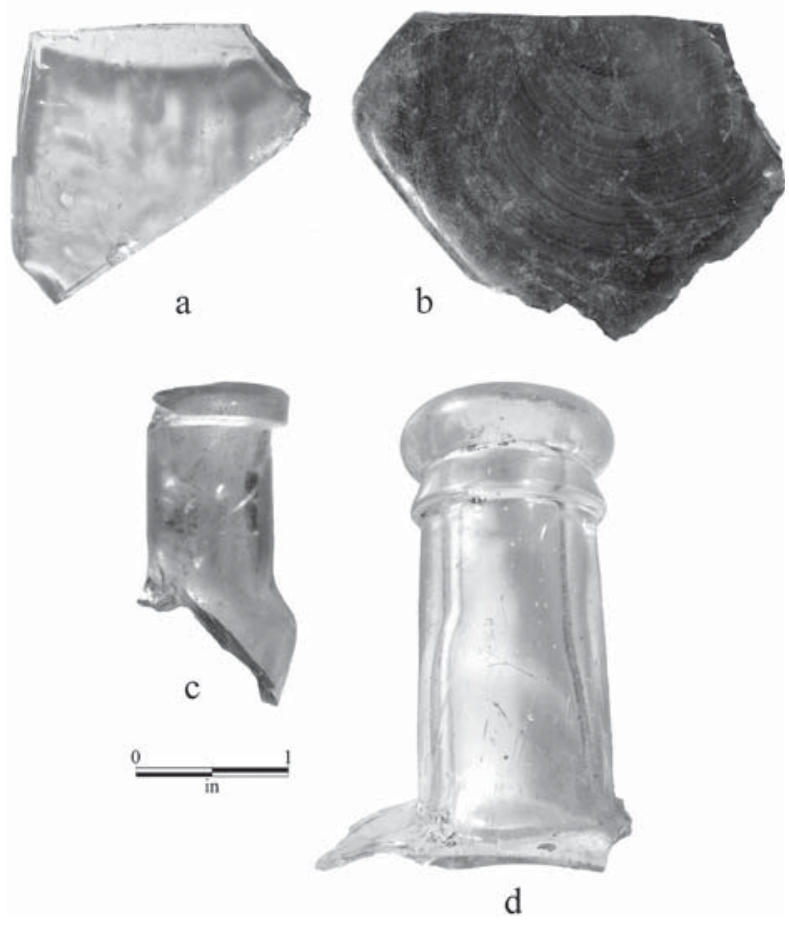

Figure 10. Bottle and snuff jar glass sherds from the Sarah's Deer Stand site: a, aqua, with embossed letters; b, snuff; c, amethyst bottle lip; d, clear bottle lip.
The sherds are from vessels that are primarily grog-tempered, but $24 \%$ also have bonetempered added to the paste. At least one sherd is from a vessel made with a naturally sandy paste, based on a detailed analysis of a small sample of sherds from the site (Perttula and Walters 2012:Table 3). Firing vessels in a reducing environment was the preferred manner employed by the Caddo potters at the site. A majority of the vessels were smoothed on one or both surfaces as part of finishing the vessels and making them ready for use for food serving, cooking, and storage. Rim and body wall thickness of the sherds analyzed in detail indicate that the vessels were built to be durable, with thick rims $(9.3 \mathrm{~mm})$ and moderately thick body walls $(6.97 \pm 1.48 \mathrm{~mm}$, range $=5.1-8.6 \mathrm{~mm}$ ).

The small sample of decorated sherds from the Handicap Deer Stand site include both utility wares $(n=19,83 \%)$ and fine wares $(n=4$, 17\%) (Figure 11a-d). The utility wares include parallel brushed body sherds $(n=7,37 \%$ of the decorated sherds) from cooking or storage jars, three sherds (16\%) with parallel incised lines, a

rim sherd with horizontal incised lines and another with diagonal incised lines (Figure 11d), two body sherds with either opposed incised or cross-hatched incised lines (Figure 11b-c), and four body sherds with punctations: either rows of fingernail punctations $(n=2)$ or tool punctations $(n=1)$, or a body sherd with a single tool punctate. The last utility ware sherd has a straight incised line adjacent to a zone of tool punctations.

Three of the four fine ware sherds are from red-slipped vessels (see Figure 11a). The use of slipping as a decorative method first become prominent on East Texas Caddo sites between ca. A.D. 1200-1450, in the Middle Caddo period, especially in the upper Neches, upper Sabine, and parts of the middle reaches of the Red River basin. The other fine ware sherd is a body sherd, probably from a carinated bowl, with a single straight engraved line on it.

The chipped stone tools from the site consist of several projectile points: one Woodland period Gary dart point, a gray chert dart point tip, and four arrow points. The Gary, var. Camden point fragment (see Schambach 1982), made from quartzite, has the narrow stem width $(13.0 \mathrm{~mm})$ of this defined variety. This particular variety of Gary point was manufactured between ca. A.D. 200-700, during the latter part of the Woodland period. Three of the points are parallel-stemmed Alba points, both unifacially and bifacially worked. The unifacial Alba points are made from non-local gray chert, while the bifacially worked specimen is on a local quartzite. The fourth point is a contracting stem unifacial Perdiz, made on a gray chert. The two different arrow points suggest that the site was used by the Caddo on two different occasions, since they are not thought to be contemporaneous (see Turner and Hester 1999); the Alba points were apparently made and used between ca. A. D. 800-1200/1300, based on the dating of the Alto phase component at the George C. Davis site (Story 2000), while the Perdiz point may have first been manufactured ca. A.D. 1200, but continued to be made and used well into the early $18^{\text {th }}$ century in East Texas (cf. Story 1995). Other chipped stone tools include two quartzite biface preform fragments, a quartzite biface fragment, and a gray chert unilateral flake tool. 


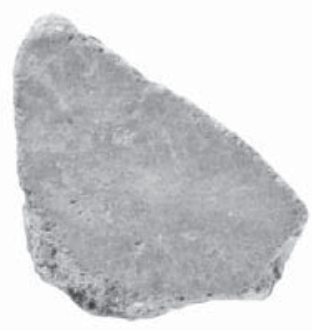

a

0
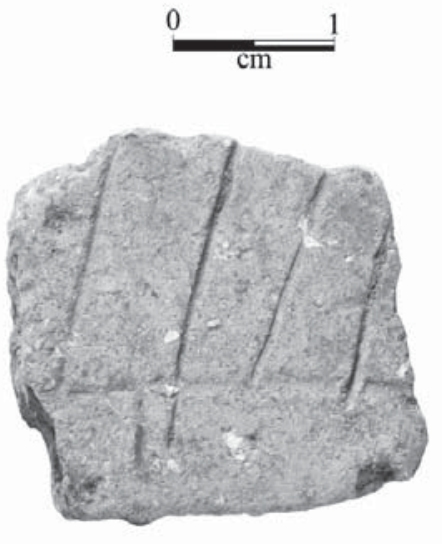

C
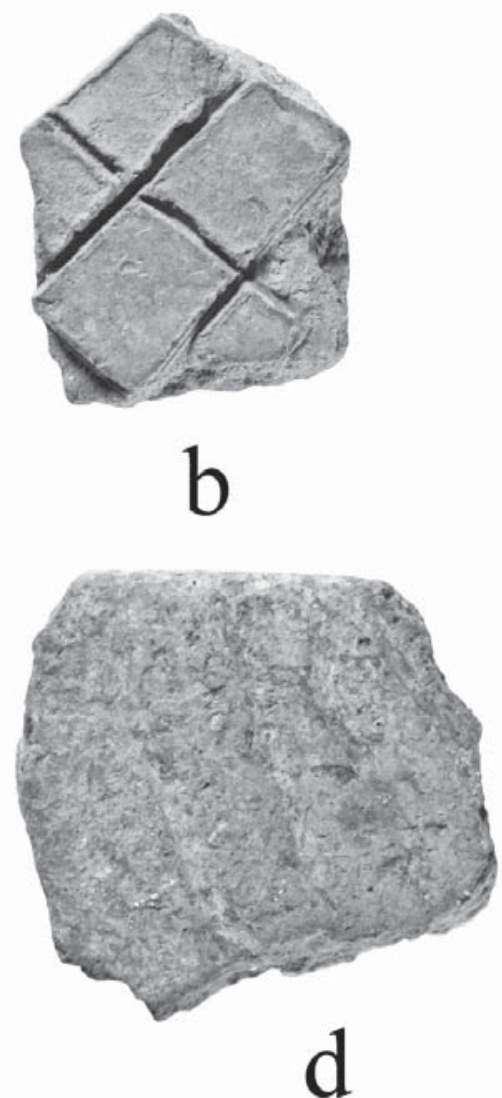

Figure 11. Decorated sherds from the Handicap Deer Stand site: a, red slipped; b-d, incised rim and body sherds.

There is a large (77 x $51 \mathrm{~mm}$ in length and width, and $37 \mathrm{~mm}$ thick) cobble-sized core with five flake removals; it is of a local tan chert, with a grayish-brown cortex. A second core has a single platform of flake removals; it is on a reddish-gray chert that is probably not from a local lithic raw material source. Two other cores are quartzite pebbles with single platform flake removals. There are 70 pieces of lithic debris in the collection, including flakes from a local quartzite (71\%), a local red chert (3\%), quartz (1\%), and several kinds of non-local chert (24\%), namely gray, light gray, dark gray, dark grayish-black, and yellowish-gray brown chert. The likely source of these latter raw materials, as well as the quartz flake, is the Red River gravels and the Ouachita Mountains of southeastern Oklahoma.

The two ground stone tools from the Handicap Deer Stand site include a quartzite mano and a ferruginous sandstone pitted stone. The mano has smoothing on one side from its use in grinding actions on a metate or grinding slab, and there is a slight circular depression on one face, suggesting it may also have been used as a pitted stone. The pitted stone has a single centrally-placed pit, but is otherwise unmodified.

Finally, there are a few pieces of unidentified animal bone in the collection from the site.

\section{Alligator Pond (41SM442)}

The Alligator Pond site is situated on two sandy upland ridge slopes that extend west to Saline Creek. The area is part of a recent pine plantation, some portions of which have been cleared for brush control; the small pine trees, brush, and weeds limit the surface visibility to $10 \%$, except in the cleared areas. The landowner also constructed a residence on the southern part of the site in 2012, which led to the collection of a large number of prehistoric artifacts during the construction work. Sediments on the landform are Attoyac fine sandy loam. The site's extent is estimated at $6000 \mathrm{~m}^{2}(1.5 \mathrm{acres})$. 
The principal artifact in the Alligator Pond site collection is sherds from aboriginal plain ware, utility ware, and fine ware ceramic vessels: 2440 sherds in all. The sherds include 30 plain rims (Figure 12a-f), 1951 plain body sherds, and 104 base sherds, as well as 353 decorated sherds; these consist of 31 rim sherds (26 from utility ware vessels and five from fine wares) and 322 body sherds. The proportion of rims in the assemblage is $49 \%$ plain ware, $43 \%$ utility ware, and $8 \%$ fine wares; these proportions indicate that not only are all three wares present in the ceramic sample, but that sherds from plain ware and utility ware vessels appear to comprise the vast bulk of the assemblage. The plain to decorated sherd ratio is a high 5.89, further reflecting the importance of the plain wares in the Alligator Pond assemblage.

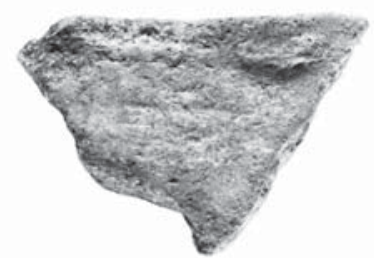

a

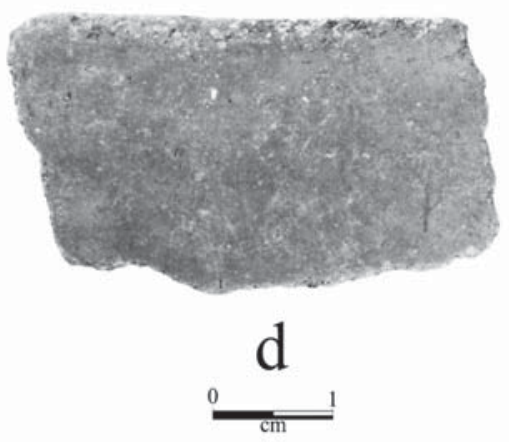

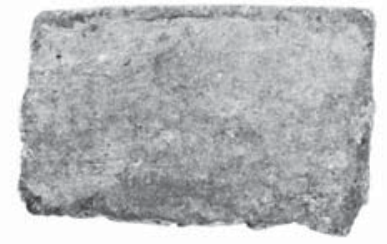

b

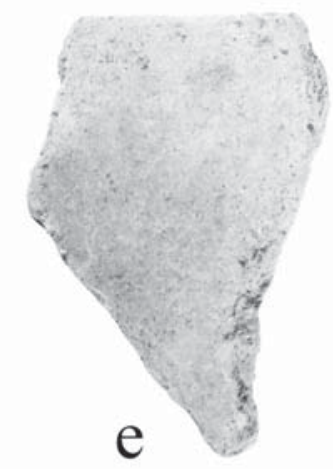

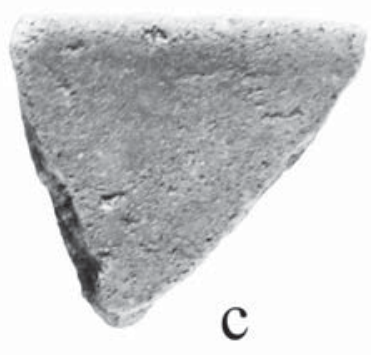

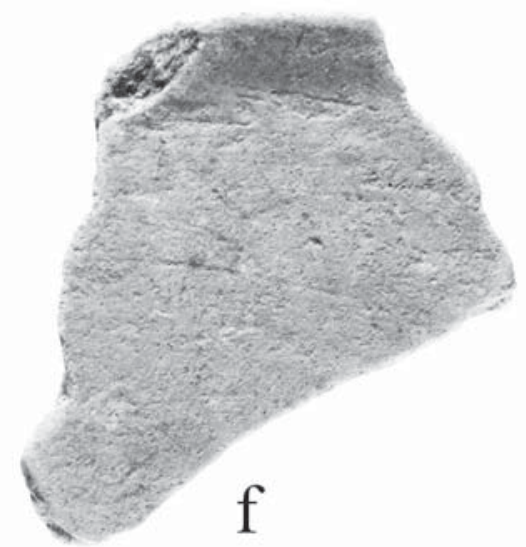

Figure 12. Plain rim sherds from the Alligator Pond site.

The sherds are from prehistoric Caddo vessels that are principally tempered with grog (92.9\%). Approximately $6.9 \%$ of the sheds are bone-tempered, along with $0.2 \%$ that have crushed hematite pieces that were employed as temper inclusions. Thirteen plain rim and body sherds are not tempered and have a naturally sandy paste; they are likely Woodland period sherds belonging to the type-variety Goose Creek Plain, var. unspecified (Aten and Bollich 2011). This kind of reduced fired sandy paste pottery was made between ca. 500 B.C. and A.D. 700, during the Woodland period in this part of East Texas, although it is more common in the Angelina River basin.

Based on the detailed analysis of a small sample of sherds from the Alligator Pond site, the sherds are from vessels that were fired in several different ways. Foremost, some $64 \%$ of the sherds are from vessels fired in a low oxygen or reducing environment, $24 \%$ were incompletely oxidized during firing, and $12 \%$ were fired in a high oxygen environment (see Perttula and Walters 2012:Table 4). Only a few sherds have been smoothed on either interior and/or exterior surfaces. The vessels at the site were coil-made, starting from a flat disk base, and they have relatively thick body walls: a mean thickness of $7.44 \pm 0.96 \mathrm{~mm}$, with a range of 5.4-9.6 mm. Vessels of different sizes and volume were obviously in use at the Alligator Pond site during its Caddo occupation.

Of the 353 decorated sherds, $70.8 \%$ are from utility ware vessels (Table 1). The utility wares are dominated by sherds from vessels with incised decorations (33.6\% of all the decorated sherds); the incised designs are almost exclusively from parallel and straight line/horizontal and vertical to simple geometric 
designs, including curvilinear, cross-hatched, diagonal, and opposed elements (Figure 13a-g). Vessels with tool and fingernail punctations - primarily including horizontal rows of punctations-comprise $19.9 \%$ of the decorated sherds from the site (Figure 14a-g). Other decorative methods less well represented in the Alligator Pond utility ware sherds are brushed, brushed-incised, and brushed-punctated (10.6\%) decorative methods (Figure 15a-c), as well as sherds with incised-punctated (4.1\%) (Figure 16a-c), appliqued (1.7\%), lip notched $(0.3 \%)$, and pinched $(0.3 \%)$ decorative elements (see Table 1$)$. The relatively low percentage of brushed sherds in the decorated sherd assemblage suggests that the Caddo occupation here took place before those occupations at the other Saline Creek Caddo sites (see below), perhaps several hundred years before.

Table 1. Decorated Sherds in the Alligator Pond Site ceramic assemblage.

\begin{tabular}{lll}
\hline Ware and Decoration & Number & Percen \\
\hline Utility Ware & & \\
& & 0.6 \\
appliqued node, body & 4 & 1.1 \\
appliqued ridge, body & & 8.8 \\
brushed, parallel, body & 31 & 0.3
\end{tabular}

\section{Table 1. Decorated Sherds in the Alligator Pond Site ceramic assemblage, cont.}

Ware and Decoration

brushed, parallel and overlying opposed incised lines, body

brushed, overlapping and fingernail punctates through brushing, body

brushed, parallel and tool punctated row through brushing

incised, straight line, body

incised, cross-hatched, rim

incised, cross-hatched, body

incised, cross-hatched, rim

incised, curvilinear, body

incised, diagonal, rim

incised, diagonal, body

incised, diagonal opposed, body

incised, parallel, body

incised-parallel-opposed, body

incised, horizontal, rim

incised, horizontal and diagonal opposed, body

incised, vertical, rim

incised, vertical-diagonal, rim

incised, curvilinear line and tool punctates in circular zone, body

diagonal incised lines and triangular incised zone, rim

diagonal opposed incised lines and tool punctated zone, body

opposed diagonal incised lines and circular punctated zone, rim

incised, parallel, adjacent to a fingernail punctated zone, body

punctated row, tool, adjacent to straight incised line, body

incised, parallel, adjacent to tool punctated zones, body

lip notched, rim

pinched, parallel, body
Number Percentage

$1 \quad 0.3$

$\begin{array}{ll}3 & 0.9\end{array}$

$1 \quad 0.3$

$31 \quad 8.8$

$2 \quad 0.6$

$\begin{array}{ll}28 & 7.9\end{array}$

$\begin{array}{ll}3 & 0.9\end{array}$

$1 \quad 0.3$

$6 \quad 1.7$

$1 \quad 0.3$

$1 \quad 0.3$

$25 \quad 7.1$

$15 \quad 4.3$

$4 \quad 1.1$

$1 \quad 0.3$

$2 \quad 0.6$

$1 \quad 0.3$

$1 \quad 0.3$

$1 \quad 0.3$

$1 \quad 0.3$

$1 \quad 0.3$

$1 \quad 0.3$

$\begin{array}{ll}6 & 1.7\end{array}$

$\begin{array}{ll}3 & 0.9\end{array}$

$\begin{array}{ll}1 & 0.3\end{array}$

$1 \quad 0.3$ 
Table 1. Decorated Sherds in the Alligator Pond Site ceramic assemblage, cont.

\begin{tabular}{lll}
\hline Ware and Decoration & Number & Percentage \\
\hline punctated, small circles, body & 1 & 0.3 \\
punctated rows, fingernail, body & 24 & 6.8 \\
punctated row, tool, rim & 5 & 1.4 \\
punctated row, tool, body & 37 & 10.5 \\
punctated, linear tool, body & 3 & 0.9 \\
Subtotal, utility ware & 250 & 70.8
\end{tabular}

\section{Fine Ware}

Bowl and Carinated Bowl

interior red-slipped, body and rim (1) $\quad 5 \quad 1.4$

int./ext. red slipped, body $\quad 17 \quad 4.8$

$\begin{array}{lll}\text { ext. red slipped, body and rim (2) } & 28 & 7.9\end{array}$

\section{Bowl and Carinated bowl}

engraved, cross-hatched, body

engraved, cross-hatched zone, body

engraved, curvilinear hatched zone, body

engraved, curvilinear, body

engraved, curvilinear, rim

engraved, curvilinear and hatched zone, body

engraved, hatched zone, body

engraved, hatched triangle, body

engraved, horizontal and diagonal and hatched zone, body

engraved, horizontal and hatched zone, rim

engraved, horizontal and vertical, rim

engraved, opposed diagonal, body

engraved, parallel, body

engraved, parallel and curvilinear, body

engraved, parallel and hatched zone, body

engraved, single straight line, body

20.6

10.3

20.6

$\begin{array}{ll}1 & 0.3\end{array}$

$3 \quad 0.9$

$1 \quad 0.3$

$3 \quad 0.9$

$1 \quad 0.3$

$1 \quad 0.3$

$2 \quad 0.6$

$1 \quad 0.3$

$11 \quad 3.1$

$1 \quad 0.3$

$1 \quad 0.3$

$12 \quad 3.4$

\section{Bottle}

engraved, cross-hatched column, pendant triangles and excised

$1 \quad 0.3$

pendant triangles, bottle, body

engraved, circle and triangle elements, body, bottle $\quad 1 \quad 0.3$

engraved, parallel, body, bottle

$1 \quad 0.3$

engraved, parallel and opposed, bottle

engraved, parallel and pendant triangle, bottle, body

engraved, triangle, bottle, body

engraved, vertical, horizontal, and opposed lines, bottle, body

excised triangle, bottle, body

$1 \quad 0.3$

$1 \quad 0.3$

$1 \quad 0.3$

$1 \quad 0.3$

$1 \quad 0.3$

Subtotal, fine ware

$103 \quad 29.2$

Totals 


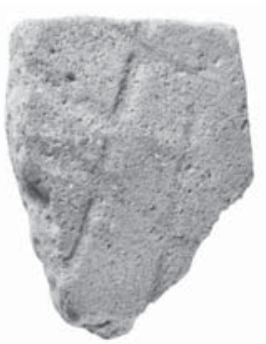

a

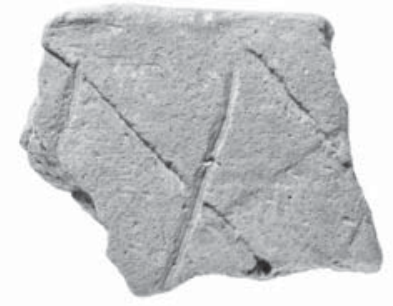

b

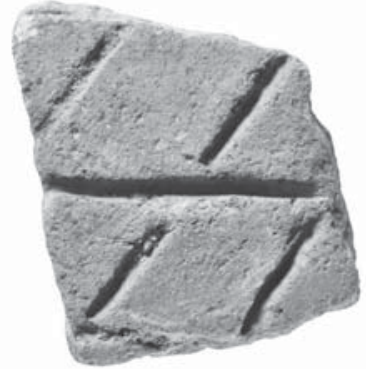

C

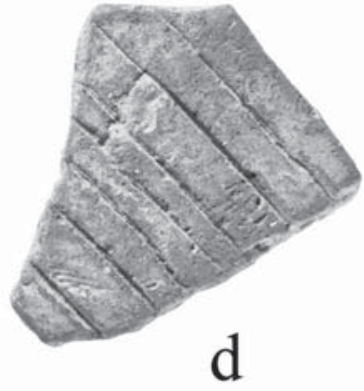

d

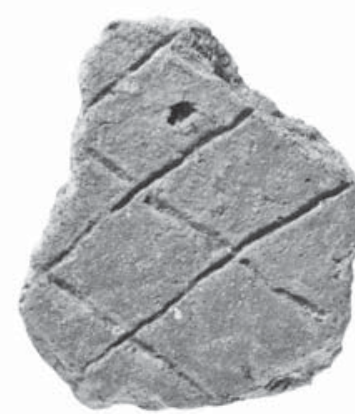

e
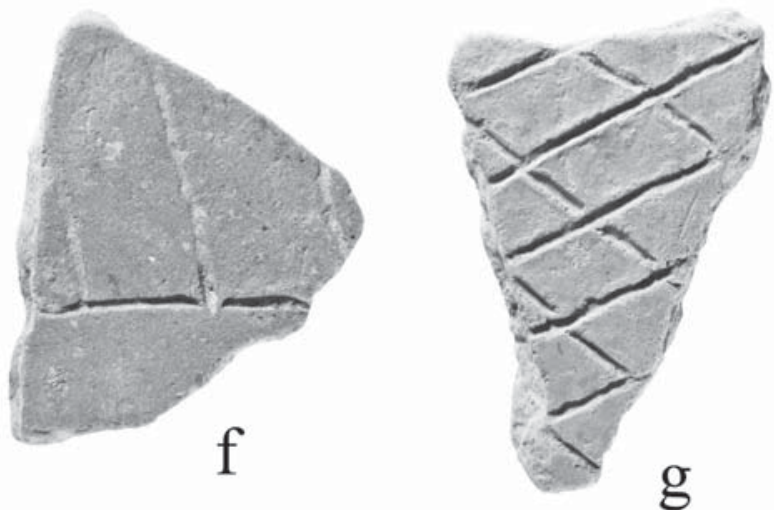

Figure 13. Incised rim and body sherds from the Alligator Pond site: a-c, e, g, cross-hatched; d, diagonal; f, opposed.

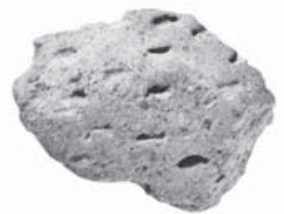

a
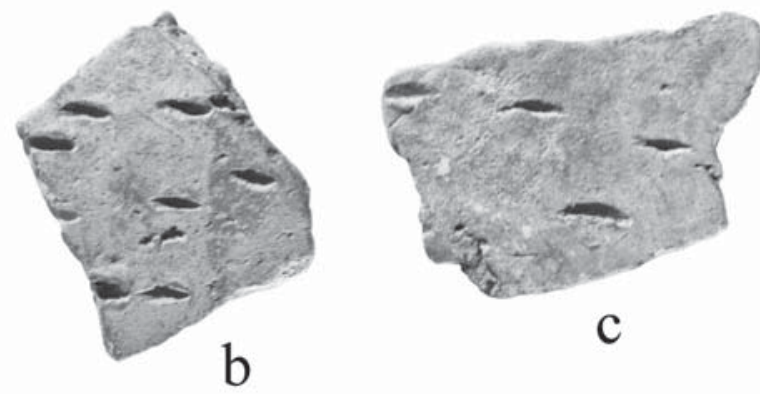

C

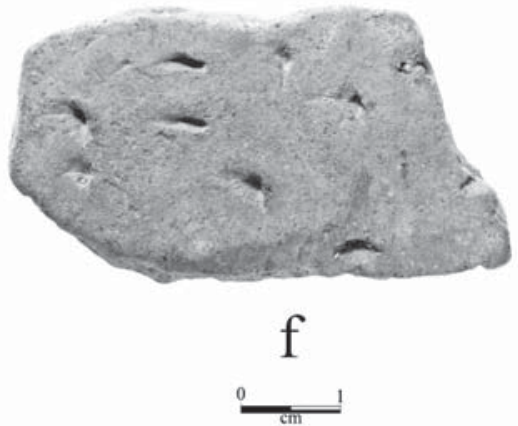

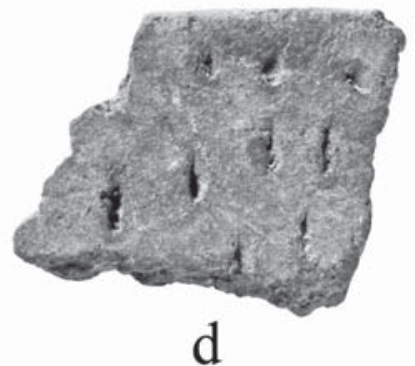

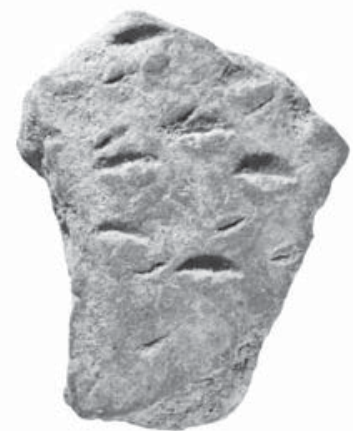

$\mathrm{g}$

Figure 14. Punctated rim and body sherds from the Alligator Pond site: a-c, e-g, body sherds; d, rim sherd. 


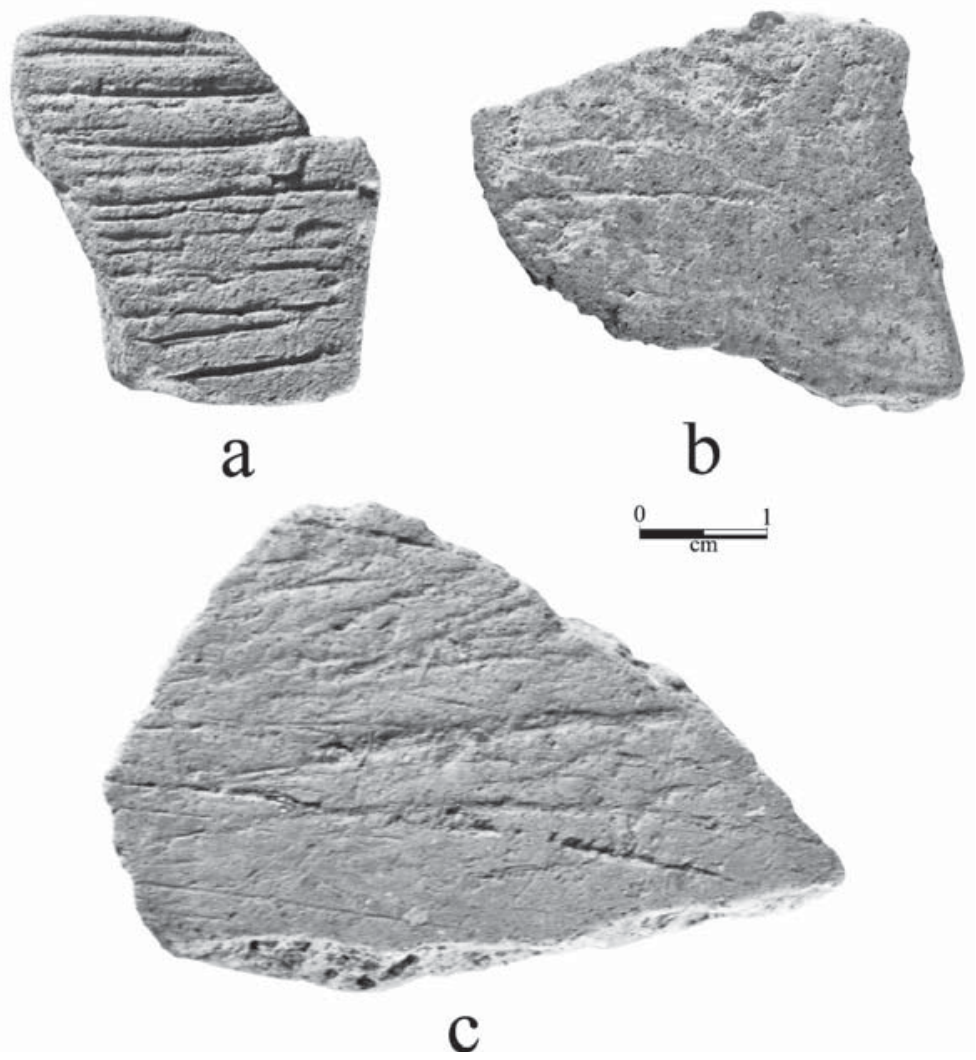

Figure 15. Brushed body sherds from the Alligator Pond site.
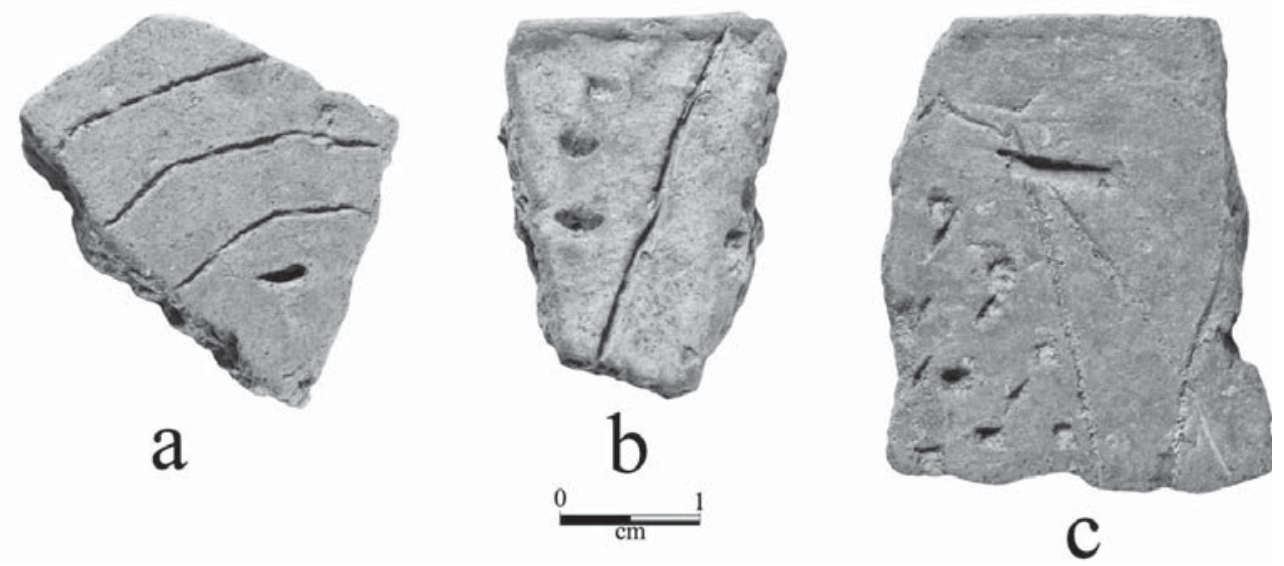

Figure 16. Incised-punctated rim and body sherds from the Alligator Pond site: a, body sherd; b-c, rim sherds.

The fine ware sherds include both engraved $(n=53)$ and red-slipped $(n=50)$ body sherds (see Table 1$)$. About $8 \%$ of the engraved sherds are from bottles (see Table 1). One of the bottle sherds has curvilinear and circular elements with excised pendant triangles (Figure 17f); these elements have been highlighted by having a hematite-rich red clay pigment rubbed in the lines. The engraved sherds have a wide variety of elements, including: straight line elements, parallel lines, diagonal lines, and cross-hatched lines, as well as hatched and excised triangles, hatched zones, pendant triangles, excised triangles, and cross-hatched columns (Figure 17a-e, g-i). One exterior-thickened rim sherd has diagonal and curvilinear engraved lines (Figure 17a). Sometimes combinations of these elements occur on the same vessel, particularly on bottles (see Perttula and Walters 2012:Figure 1b-d). The considerable frequency of red-slipped sherds (14.1\% of all 


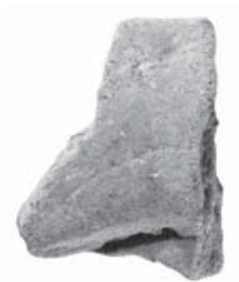

a

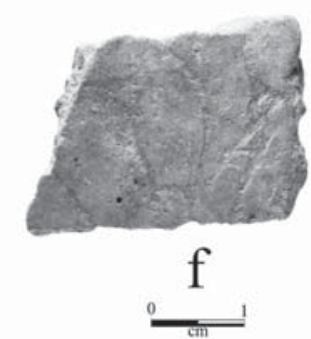

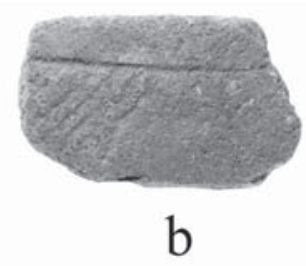

$\mathrm{b}$

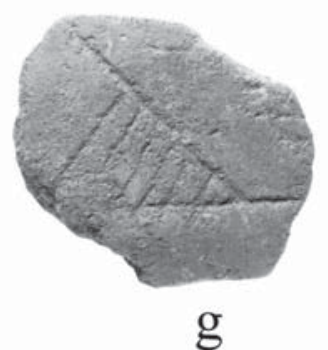

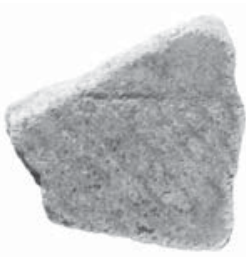

c
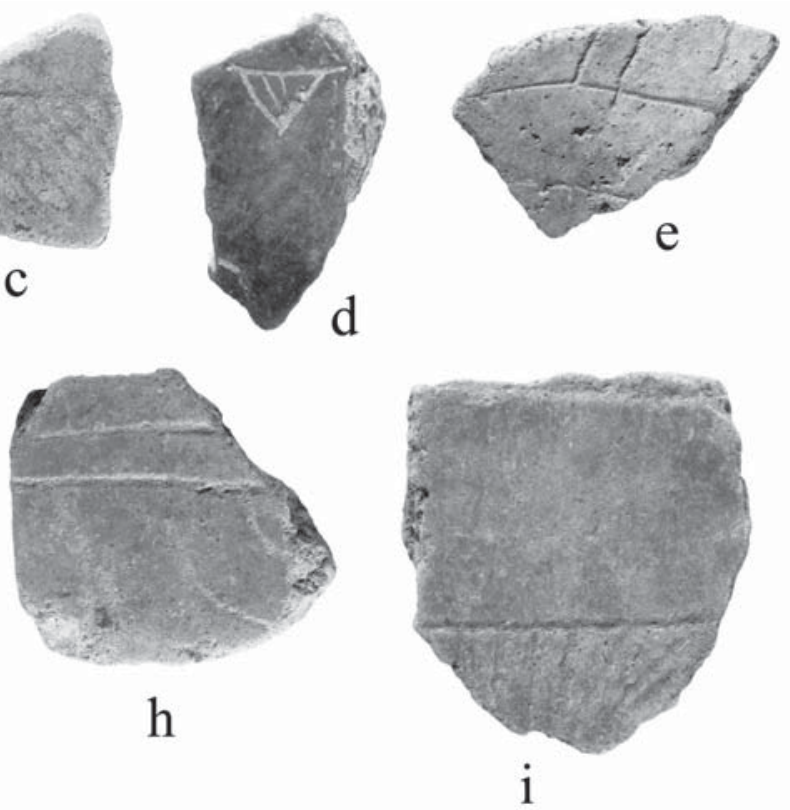

Figure 17. Fine ware engraved sherds from the Alligator Pond site: c-e, g-i, body sherds; a-b, rim sherds; f, bottle sherd.

the decorated sherds, see Table 1) in the fine wares at the Alligator Pond site is also notable (Figure 18a-d), especially given regional trends in the use and discard of red-slipped vessels in a number of parts of East Texas in Middle Caddo period contexts.

There are 900 chipped stone artifacts in the Alligator Pond site assemblage. This includes 84 chipped stone tools (mainly dart points [ $n=24]$, arrow points [ $n=24]$, and flake tools [n=21]), 775 pieces of lithic debris from tool manufacture and maintenance activities, and 41 cores (core fragments, single platform cores, multiple platform cores, and tested cobbles/pebbles); only $4.9 \%$ of the cores are on non-local lithic raw materials (a grayish-brown chert and a yellow novaculite), with most of them on local quartzite. The cores are primarily on local pebble-sized stream gravels with smoothed cortical surfaces.

Almost 35\% of the chipped stone tools are made on non-local cherts, many of them flake tools (expedient tools with use wear/retouch on one or more flake edges, graver, and scraper fragments), which is a considerable amount; more than $90 \%$ of the flake tools are on non-local lithic raw materials. This proportion of non-local lithic raw material use in the tools is matched by the fact that about $37 \%$ of the lithic debris from the site is from the manufacture and/or resharpening of tools made from non-local cherts (i.e., white, whitish-red, gray, grayish-white, dark brown, light gray, dark grayish-brown, grayish-brown, grayish-red, and brownish-gray cherts) as well as gray, white, and yellow novaculite $(\mathrm{n}=11,1.4 \%)$ and quartz $(\mathrm{n}=3,0.4 \%)$. The most common non-local chert in the lithic debris is a gray chert (about $35 \%$ of the non-local lithic raw materials); some pieces have a limestone-covered cortex, which suggests it originated in Central Texas source areas. The novaculite and quartz originate in Ouachita Mountains source areas, well to the north of the site. About $52 \%$ of the lithic debris is on local quartzite, both fine- and coarse-grained; much of it is also heat-treated to improve its knappability. The remainder of the local lithic debris includes petrified wood $(4 \%)$, ferruginous sandstone $(0.3 \%)$, and earth-toned cherts (i.e., red, brown, yellow, and tan colors, $7 \%$ ).

The chipped stone arrow points from the Alligator Pond include six fragments, four oval-shaped preforms (evidence of on-site arrow point manufacture activities), one Bassett (Figure 19g), two Perdiz (Figure 19c, e) with narrow contracting stems, another possible Perdiz (Figure 19j), four Alba, two Steiner (Figure 19b, f), one Catahoula (Figure 19h), and three expanding stem, corner-notched arrow points made from the local quartzite (Figure 19a, d, i). These latter points may be identified as either Homan or Scallorn points, with both types found in pre-A.D. 1200 Caddo contexts in East Texas sites. Other pre-A.D. 1200 arrow points in 

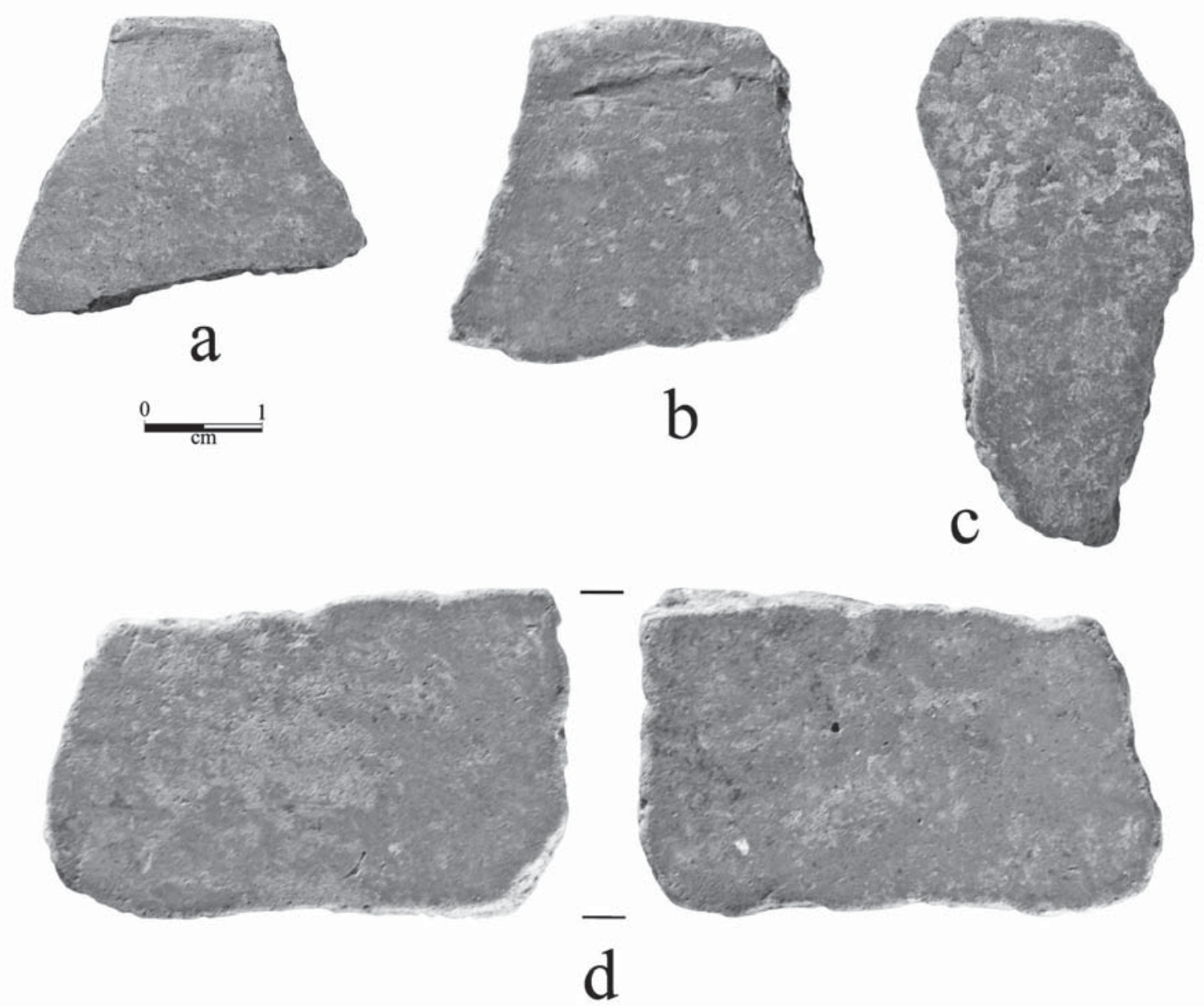

Figure 18. Red-slipped rim and body sherds from the Alligator Pond site: $a-b$, rim sherds; $c-d$, body sherds .

the collection include the Alba, Steiner, and Catahoula forms, while the Bassett and Perdiz points suggest some use of the site as late as the $15^{\text {th }}$ century A.D. Approximately $38 \%$ of the arrow points are made from non-local lithic raw materials (primarily chert), while the remainder are on local quartzite.

There is one polished petrified wood celt in the collection. This was a woodworking tool also used by the Caddo during their occupation at Alligator Pond.

There are a number of dart ponds in the Alligator Pond site collection (Figure 20). The Gary points $(\mathrm{n}=5)$ at the site are the narrow stemmed var. Camden specimens (Figure 20e); there is also a Gary point preform in the collection from the Alligator Pond site. Their occurrence at the site is indicative of some use during the latter part of the Woodland period. Other Woodland period points in the collection include a cf. Darl ( $\mathrm{n}=1$ ), one Kent point (Figure 20d), one Ellis point (Figure 20a), and a Godley point. These various dart points are likely associated with the previously mentioned Goose Creek Plain, var. unspecified sandy paste pottery sherds from the site.

The Yarbrough and Williams points at the Alligator Pond site are dart point types that characterize the Late Archaic in East Texas, as is the one Morrill point (see Figure 20b, g-j), and it is estimated that they date between ca. 5000-3000 years old. These points, and probably several of the other chipped stone tools, represent the earliest occupation on the landform, except for one Johnson point (dating ca. 6000 B.P.) made from a gray novaculite and a side-notched point made from local quartzite (see Figure 20f). Only about $16 \%$ of the dart points in the collection are made from non-local lithic raw materials (chert or novaculite). 


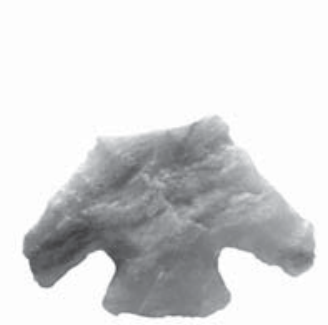

a

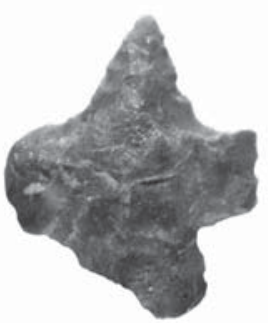

b

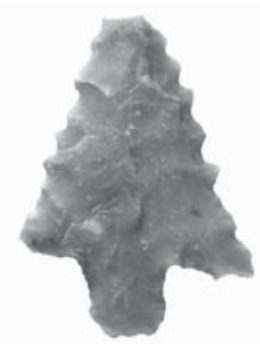

C

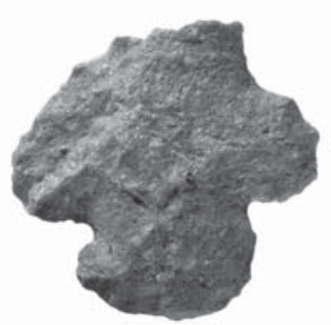

d

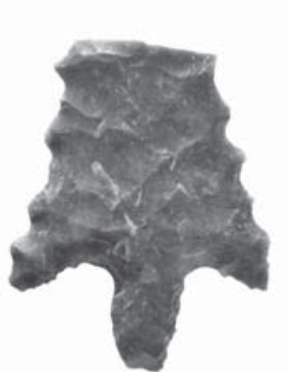

e

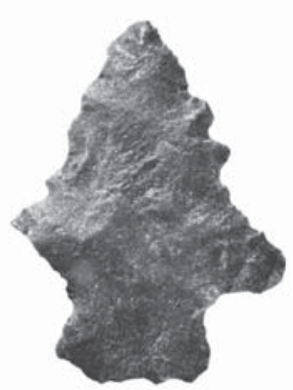

f

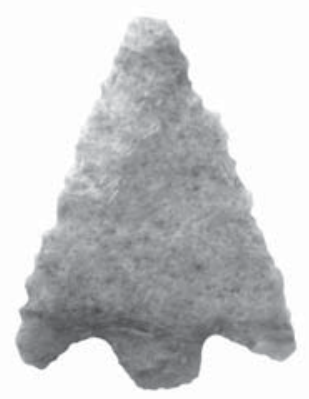

g

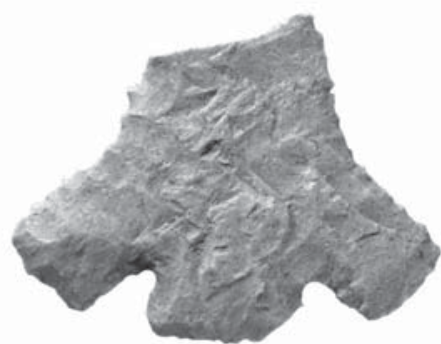

$\mathrm{h}$
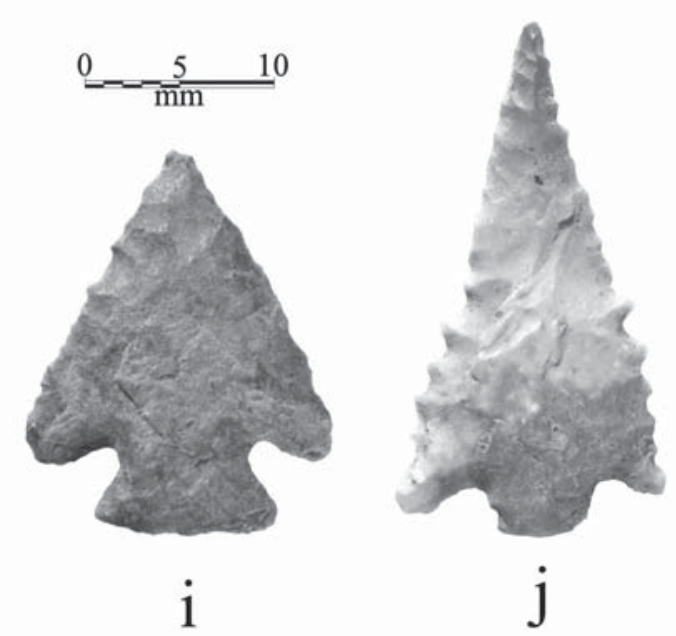

$\mathrm{j}$

Figure 19. Stemmed arrow points from the Alligator Pond site: a, d, i, corner-notched; b, f, Steiner; c, e, Perdiz; g, Bassett; h, Catahoula; j, possible Perdiz point.

There are also biface fragments and indeterminate bifaces discarded during failed manufacturing efforts as well as a bifacial knive (Figure 21f). These include biface preform fragments ( $n=3,100 \%$ quartzite) and biface tip and blade fragments ( $\mathrm{n}=8,87 \%$ quartzite, $13 \%$ petrified wood).

The flake tools $(\mathrm{n}=21)$ at the Alligator Pond site include both expedient tools with edge retouching and evidence of use (see Figure 21a-c) as well as scraping tools (see Figure 21d-e) and a grayish-brown chert graver; these tools were made almost exclusively with non-local chert raw materials. The expedient tools have retouch/use wear on one edge ( $\mathrm{n}=10,100 \%$ non-local gray, grayish-brown, and dark gray chert) or two edges ( $n=6,83 \%$ non-local gray, grayish-brown. and grayish-white chert and $17 \%$ quartzite). The side scraper fragments (see Figure 21d-e) are on non-local light gray and grayish-brown cherts.

In addition to the chipped stone artifacts, there are 24 ground stone tools in the Alligator Pond site collections. This includes nine quartzite and ferruginous sandstone manos, with ground smoothed areas on 


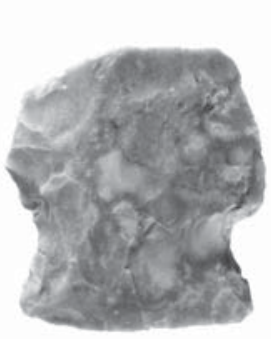

a

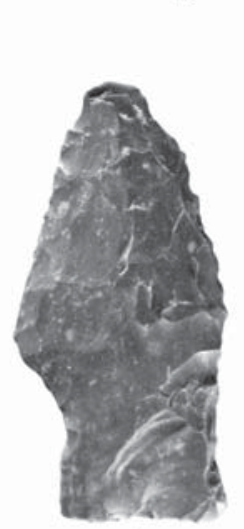

d

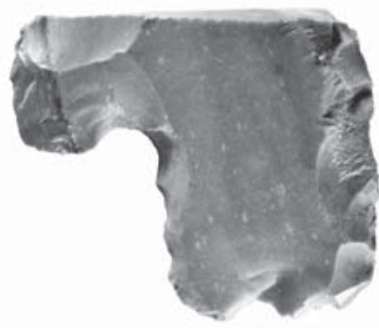

b

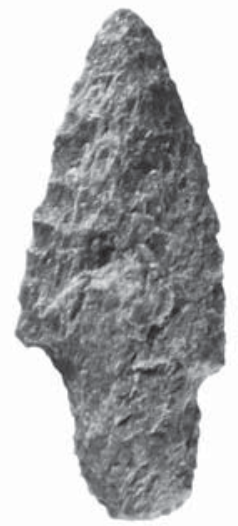

$\mathrm{e}$

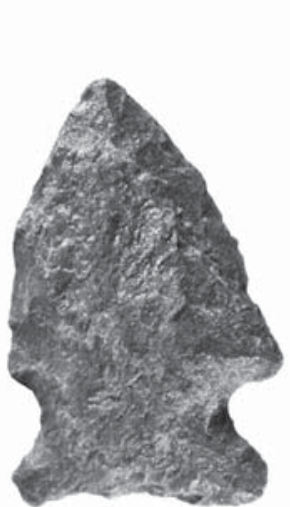

f

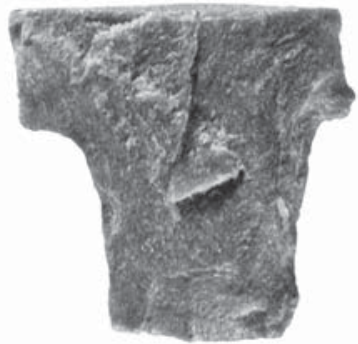

c

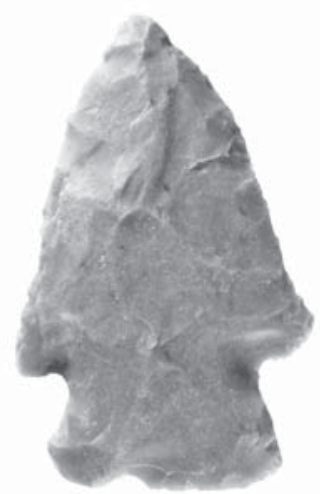

g

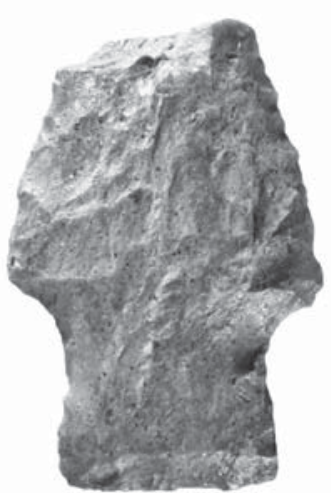

$\mathrm{h}$
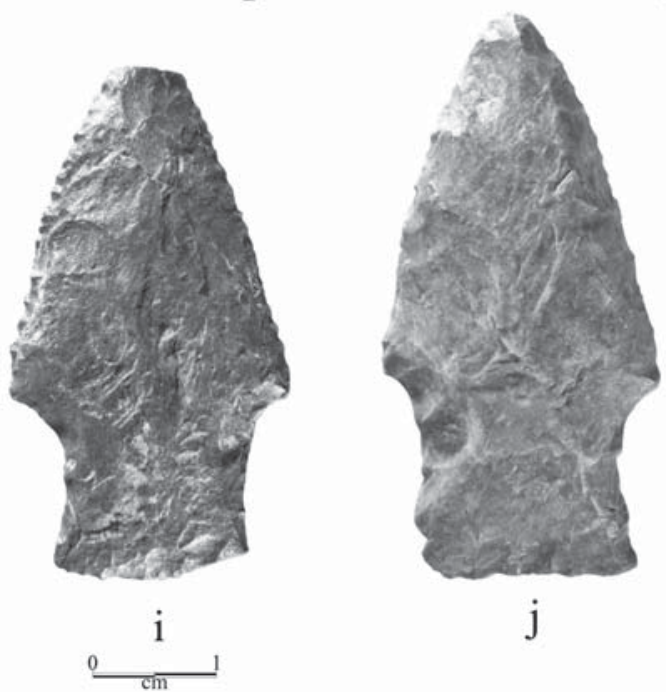

Figure 20. Dart points from the Alligator Pond site: a, Ellis; b, Morrill; c, Bulverde; d, Kent; e, Gary; f, unidentified side-notched; g-h, Williams; i-j, Yarbrough.

either one or both surfaces. The manos range from 103-114 $\mathrm{mm}$ in length, $82-88 \mathrm{~mm}$ in width, and 35-45 $\mathrm{mm}$ in thickness. There are two sandstone or ferruginous sandstone mano/pitted stones in the collection. There is a ferruginous sandstone metate with a $15 \mathrm{~mm}$ deep concave depression on one side in its center, this being the active grinding and pounding area. The metate is $175 \mathrm{~mm}$ in length, $170 \mathrm{~mm}$ in width, and $50 \mathrm{~mm}$ thick. Four grinding slabs, made from local ferruginous sandstone, are in the collection (Figure 22). There are also five coarse-grained ferruginous sandstone pitted stones with circular depressions on one or both sides (Figure 23). Another ferruginous sandstone cobble has battered pits on both cobble surfaces. Also in the collection is a fragment of a possible ferruginous sandstone axe fragment. The final ground stone tool is the poll end of a Caddo tradition quartzitic sandstone celt fragment; this material originates in the Ouachita Mountains of southeastern Oklahoma, but is also present in gravels in the middle reaches of the Red River valley, well north of Saline Creek in East Texas. 


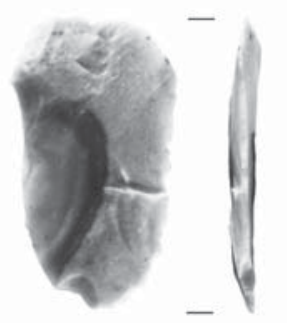

a
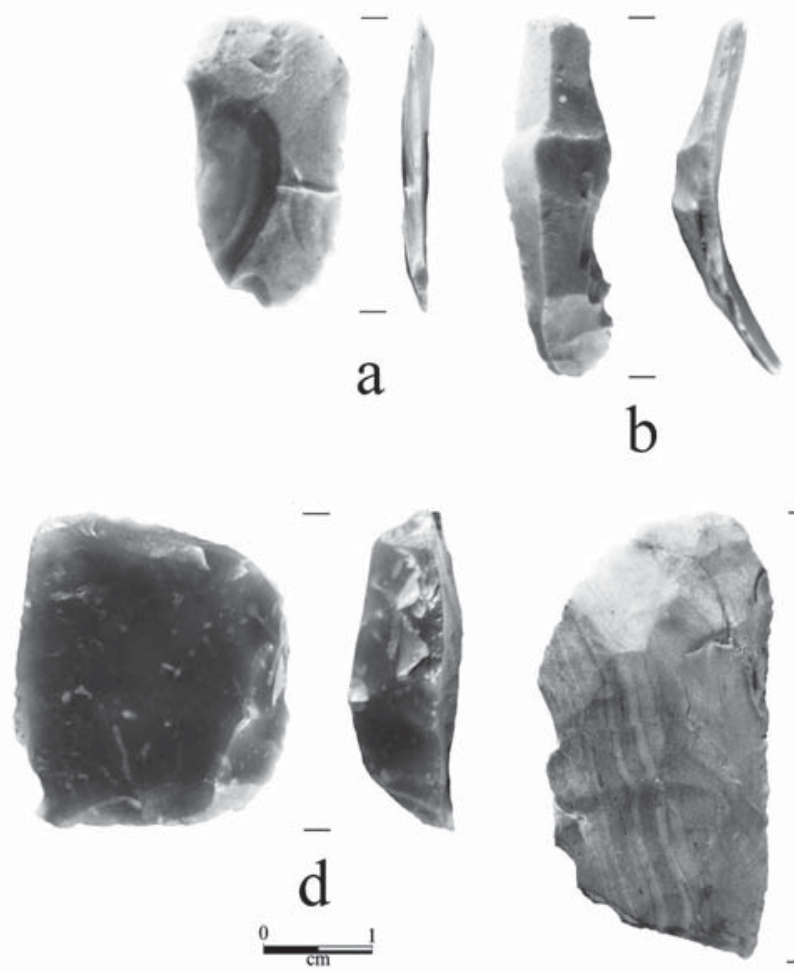

b

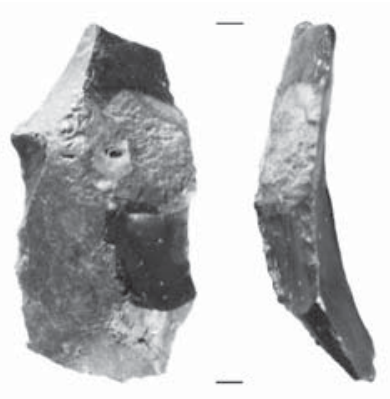

$\mathrm{C}$

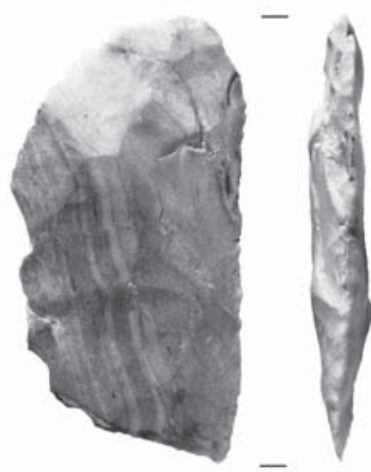

e

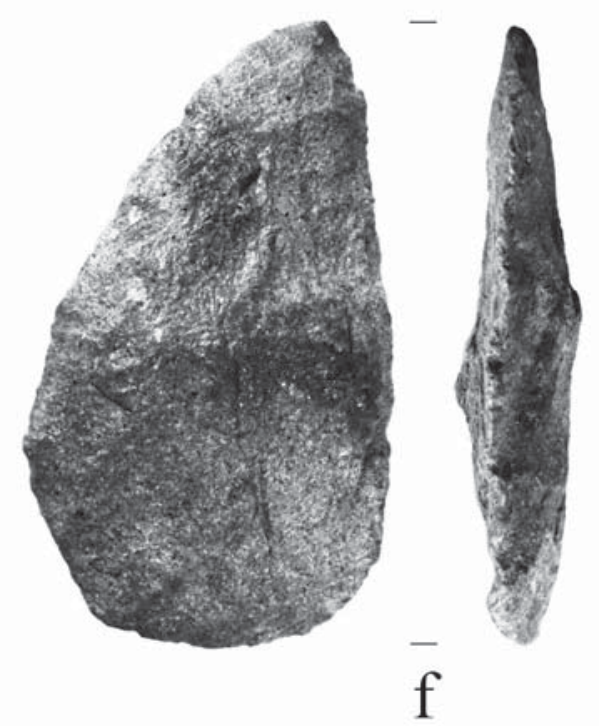

Figure 21. Flake tools, scrapers, and bifacial knives at the Alligator Pond site: a-c, unilateral flake tools; d-e, scraping tools; e, bifacial knive.

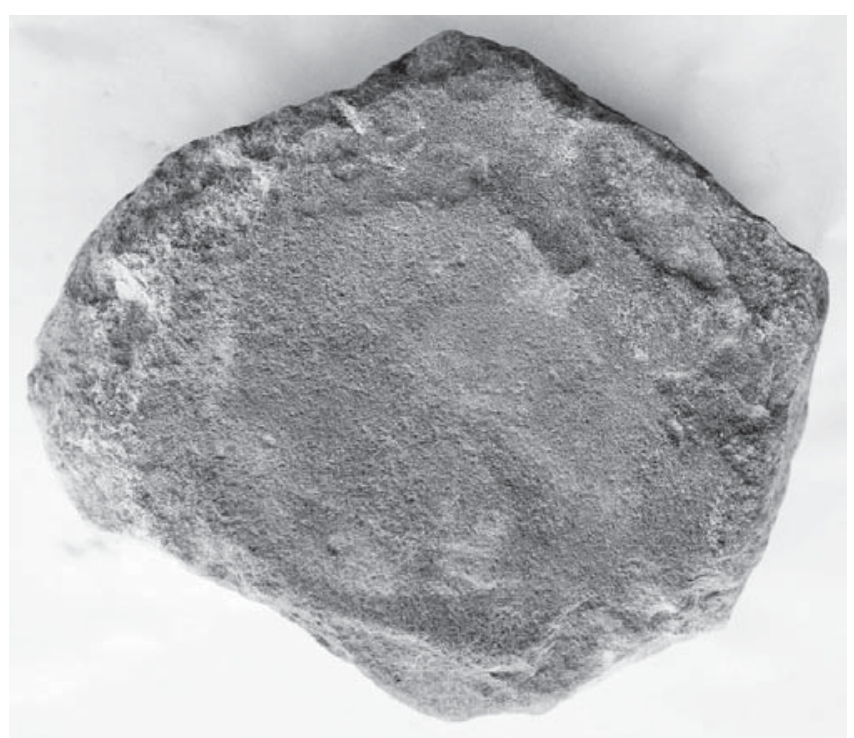

Figure 22. Ferruginous sandstone grinding slab from the Alligator Pond site. The slab is $19 \times 17 \mathrm{~cm}$ in length and width.

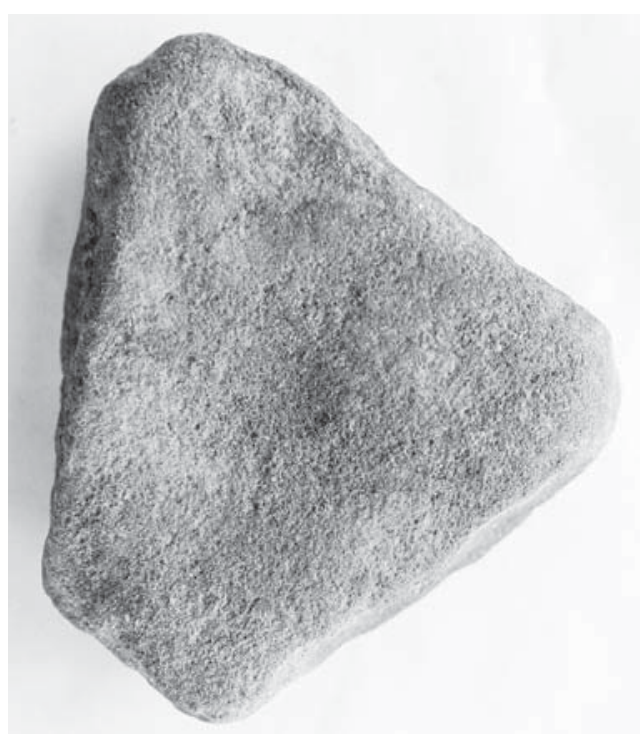

Figure 23. Ferruginous sandstone pitted stone from the Alligator Pond site. The pitted stone is $12 \times 10.6 \mathrm{~cm}$ in length and width. 
Twelve pieces of fire-cracked rock (FCR) from the hot rock cooking of plant foods in ovens and pits are in the Alligator Pond site collections. Eleven of the FCR are quartzite, and the other is hematite, both local stone raw materials.

There is an early $19^{\text {th }}$ century historic component at the Alligator Pond site. This is marked by one honey-colored blade gunflint (Figure 24d), probably a French gunflint, two English blade gunflints (Figure 24e-f), several ceramic sherds, and two small glass seed beads. The ceramic sherds include two refined earthenware rim and body sherds, possibly pearlware, that have hand-painted floral decorations (Figure 24a-b), and an alkaline-glazed stoneware crock sherd (Figure 24c). The seed beads are translucent light and dark aqua-colored.

Finally, there are six animal bones (one burned) in the collection from the site.

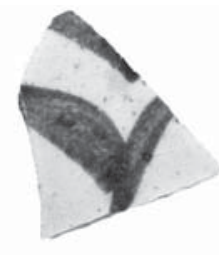

a

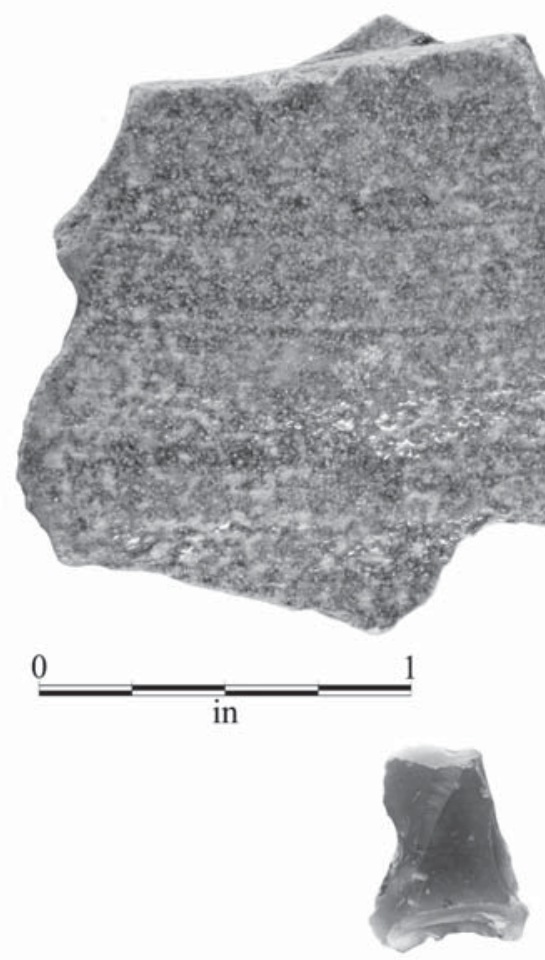

d

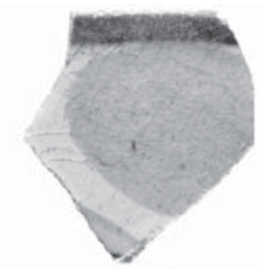

b

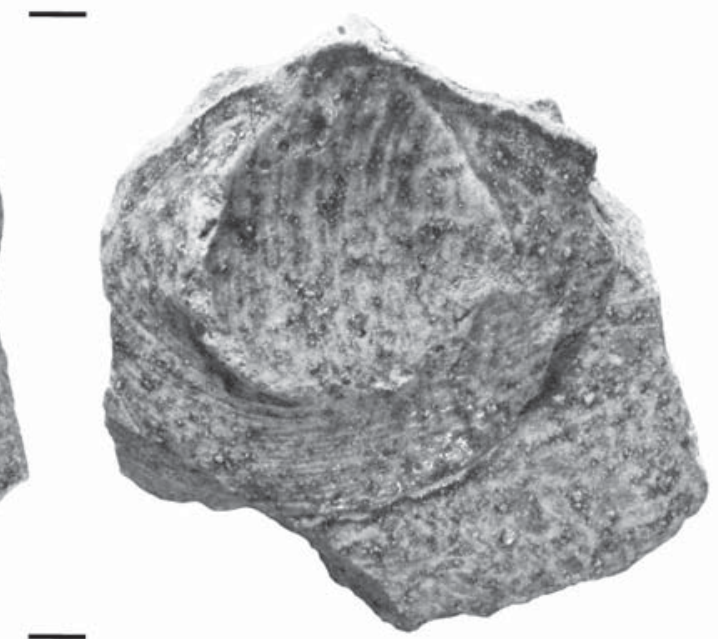

c

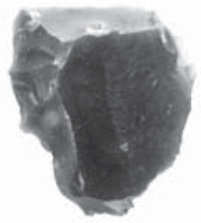

e

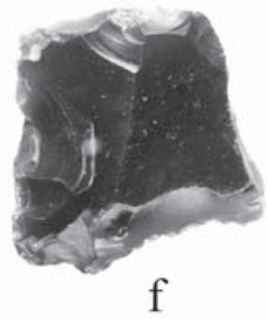

Figure 24. $19^{\text {th }}$ century artifacts from the Alligator Pond site: a-b, hand-painted refined earthenware sherds; $\mathrm{c}$, stone ware sherd; d-f, blade gunflints. 


\section{Thacker Farm House (41SM444)}

The Thacker Farm House site is located on a gravelly upland landform about $1.1 \mathrm{~km}$ east of Saline Creek. Soils are a Redsprings very gravelly sandy loam (2-5\% slopes). The site area, estimated at $2500 \mathrm{~m}^{2}$ ( 0.62 acres), is in a cleared orchard, but orchard plantings and weeds limit the surface visibility to $10 \%$.

A total of 219 Caddo ceramic vessel sherds are in the collections from the Thacker Farm House, including 161 plain sherds (two rims, 150 body sherds, and nine base sherds) and 58 decorated sherds. The plain to decorated sherd ratio is a moderate 2.77 .

The sherds are from grog-tempered vessels, with some vessels also having bone (5\%) and crushed hematite temper inclusions. The detailed analysis of a sample of the sherds suggests that most of the sherds are from unsmoothed vessels that were fired in a reducing environment, while $20 \%$ are from vessels that were incompletely oxidized during firing. Vessel walls of these vessels were relatively thick (mean thickness of $8.3 \pm 0.9 \mathrm{~mm}$ ), likely because vessels at the site were large in size, and some may have served as durable storage vessels with extra-thick body walls.

The 58 decorated sherds are primarily from utility ware vessels ( $n=52,89.6 \%$ of the decorated sherds), with only six engraved fine wares (10.3\% of the decorated sherds) (Figure 25). The utility ware sherds include brushed $(n=28)$, brushed-incised $(n=3)$, tool punctated $(n=2)$, incised $(n=16)$, brushed-punctated $(\mathrm{n}=1)$, incised-appliqued $(\mathrm{n}=1)$, and incised-punctated $(\mathrm{n}=1)$.

The brushed and brushed-incised body sherds have parallel brushing marks (see Figure 25b-d), likely from jars with vertical brushing, but the orientation of the brushing cannot be determined with confidence. All 15 incised body sherds have straight to parallel incised lines, but again the orientation of the incised

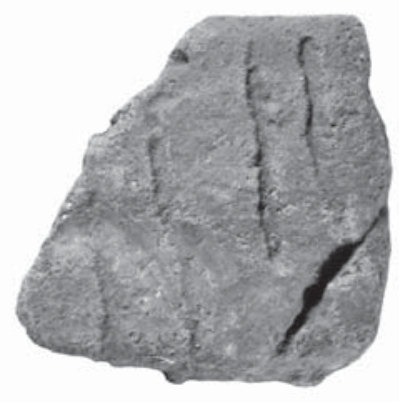

a

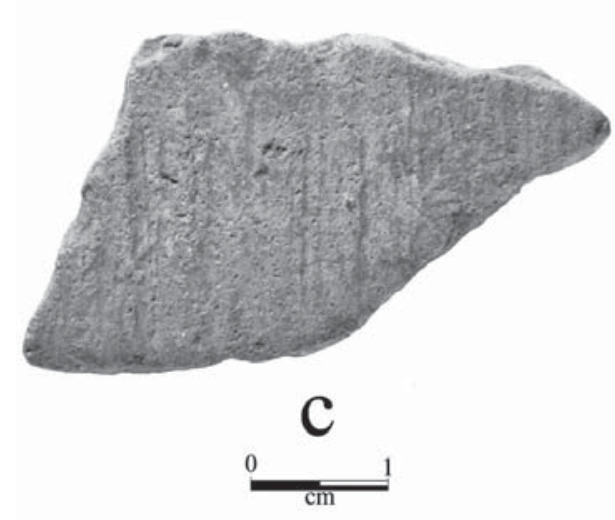

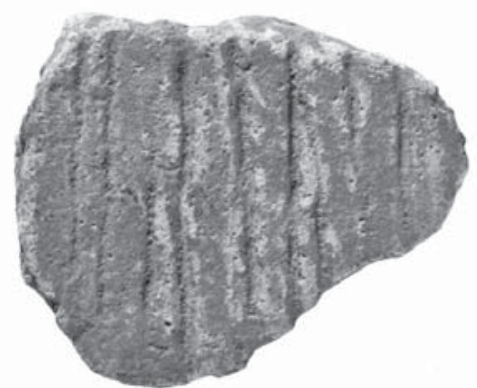

b

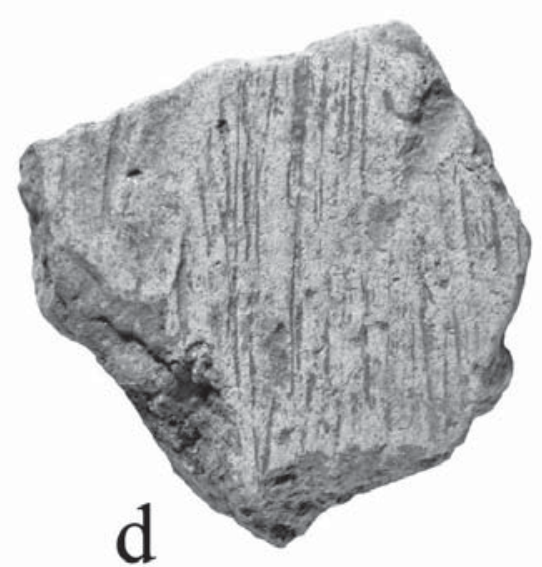

Figure 25. Decorated sherds from the Thacker Farm House site: a, incised rim; b-d, parallel brushed body sherds. 
decorations is not known. The one incised rim has diagonal opposed lines (see Figure 25a). One body sherd has parallel brushing, with tool punctates pushed through the brushing; this is a common vessel decoration on utility wares in both Middle and Late Caddo times in East Texas. Two body sherds have rows of tool punctations. Another body sherd has parallel incised lines adjacent to a straight appliqued ridge; the latter was likely used to divide a vessel body into quadrants filled with different decorations; in this case, the quadrants probably were filled with vertical incised lines. Finally one incised-punctated rim sherd from a Maydelle Incised vessel has opposed diagonal incised lines that create triangular zones: these zones are filled with tool punctates.

One fine ware rim sherd from a carinated bowl has two horizontal engraved lines on the rim panel. One of the body sherds has closely-spaced parallel engraved lines, another has diagonal engraved lines, and one other has a straight engraved line. The last two engraved body/lower rim sherds (see Perttula and Walters 2012:Figure 1e) have a hatched bracket or divider element, likely sherds from a Poynor Engraved, var. Hood vessel (see Perttula 2011:Figure 6-64e).

The lithic assemblage from the site is sparse, including only two dart points, a gray chert bifacial tool fragment, and 15 pieces of lithic debris. The first dart point is a Late Archaic Yarbrough point made from a locally available quartzite, while the second is a heat-treated quartzite Kent point of likely Woodland period age. Both local (quartzite, petrified wood, brownish-red chert, and brown chert) and non-local (gray chert, dark brown chert, light gray chert, banded grayish-brown chert, and white chert) lithic raw materials were knapped at the site, although this was done sparingly; about $40 \%$ of the lithic debris has stream-rolled cortical remnants, indicating that the raw material was gathered from local stream gravels.

\section{SUMMARY AND CONCLUSIONS}

Overall, the character of the lithic and ceramic artifacts that have been collected from the four Saline Creek sites seems to indicate that this part of the valley was first settled by aboriginal peoples about 6000 years ago, as indicated by the Johnson point and an unidentified side notched from the Alligator Pond site (41SM442), but the most intensive occupation started at the beginning of the Late Archaic period, about 5000 years ago. This period is marked by the recovery of Williams and Yarbrough dart parts at three of the sites, a Morrill point at one of the sites, Trinity, Bulverde, Ellis, or Edgewood points at two sites, as well as a range of chipped (i.e., bifacial, unifacial, and gouges) and ground stone tools (Table 2). Likewise, during the latter part of the Woodland period, all four of the four Saline Creek sites were occupied-as evidenced by the documentation of Gary, var. Camden dart points at three sites, along with Godley and Kent dart points (see Table 2) - by Woodland peoples ancestral to the Caddo peoples that lived in East Texas after ca. A.D. 800/850. The Alligator Pond site (41SM442) also had 13 sherds from Goose Creek Plain, var. unspecified sandy paste Woodland period vessels. The occurrence of this kind of ceramic sherds at the site, which are often taken as one indicator of the development of a more sedentary lifeway, suggests that the occupation during this time at the Alligator Pond site may have been more than a hunting and food processing camp, but a camp where the Woodland peoples may have stayed for a longer period of time during a seasonal occupation. Projectile point to ground stone tool ratios from the four sites suggest that hunting was a major pursuit at each of the sites, although plant foods were processed at them as well using ground stone manos, metates, and pitted stones. 
Table 2. Selected lithic comparisons between the Saline Creek sites.

\begin{tabular}{|c|c|c|c|c|}
\hline Sites & $\begin{array}{l}\% \text { Non-local } \\
\text { chert artifacts }\end{array}$ & $\begin{array}{l}\text { Arrow Points } \\
\text { and Types }\end{array}$ & $\begin{array}{l}\text { Dart Points } \\
\text { and Types }\end{array}$ & $\begin{array}{l}\text { Projectile Point to } \\
\text { Ground stone Ratio }\end{array}$ \\
\hline SM440 & 24.8 & $\begin{array}{l}\text { 14, preform (1), } \\
\text { Alba (3), } \\
\text { Scallorn (1), } \\
\text { UID (2), } \\
\text { fragments (7) }\end{array}$ & $\begin{array}{l}\text { 17, Gary (5), } \\
\text { Yarbrough (5), } \\
\text { Edgewood (3), } \\
\text { Trinity (1), } \\
\text { UID parallel- } \\
\text { stemmed (1), } \\
\text { fragments (2) }\end{array}$ & $31: 6$ \\
\hline SM441 & 23.8 & $\begin{array}{l}\text { 4, Alba (3), } \\
\text { Perdiz (1) }\end{array}$ & $\begin{array}{l}\text { Gary (1), } \\
\text { dart point tip (1) }\end{array}$ & $6: 2$ \\
\hline SM442 & 36.0 & $\begin{array}{l}\text { 24, Scallorn \& } \\
\text { Homan (3); preforms } \\
\text { (4); fragments (6); } \\
\text { Bassett(1), } \\
\text { Perdiz (2), } 1 \text { cf. } \\
\text { Perdiz, Alba (4) } \\
\text { Steiner (2), } \\
\text { Catahoula (1) }\end{array}$ & $\begin{array}{l}\text { 24, Gary (6), } \\
\text { Williams (2) } \\
\text { Yarbrough (4), } \\
\text { cf. Darl (1), Kent (1), } \\
\text { Godley (1), Bulverde (1), } \\
\text { Ellis (1), Johnson (1), } \\
\text { Morrill (1); } \\
\text { unidentified forms (2), } \\
\text { fragments (3) }\end{array}$ & $48: 24$ \\
\hline SM444 & 44.4 & - & $\begin{array}{l}\text { Yarbrough (1) } \\
\text { Kent (1) }\end{array}$ & $2: 0$ \\
\hline Totals & - & 42 & 45 & $87: 32$ \\
\hline
\end{tabular}

A notable characteristic of the lithic assemblages from the Saline Creek sites is the use of non-local chert artifacts in the chipped stone tools, the polished celts, and the chipped stone lithic debris (see Table 2 ). At the Thacker Farm House site, the percentage of non-local chert artifacts is $44 \%$, while the other three have comparable, but lower, percentages of non-local cherts in their assemblages (23.8-36\%). While it is uncertain just how many of the chipped stone artifacts from the sites can be associated with the prehistoric Caddo occupations, the fact that the Thacker Farm House site is apparently the latest occupied site among the four Saline Creek sites, it does open up the tantalizing possibility that the later Caddo peoples that settled in the basin had a better and broader access to non-local sources of non-local cherts (either by direct procurement or through trade and exchange). The other Caddo peoples that settled into the basin did have a ready access to non-local chert raw materials, but they also had to depend on local raw materials such as coarse- and fine-grained quartzite, petrified wood, and ferruginous sandstone.

The major settlement of the Saline Creek valley was by the ancestors of modern Caddo people. During the Caddo occupation of the Saline Creek sites, including a relatively intensive and early occupation at the Alligator Pond, arrow point preforms, arrow point fragments, and several identifiable arrow point styles suggest the sites were first occupied before ca. A.D. 1000 and continued to be occupied episodically and on a generational basis until sometime after ca. A.D. 1300. Given what we know about the ceramics from these four sites, the Alligator Pond site was likely occupied the earliest during the Caddo era, while the other three-Sarah's Deer Stand (41SM440), Handicap Deer Stand (41SM441), and Thacker Farm House 
(41SM444) - may have been occupied at least one or two centuries later, but between them, more or less contemporaneously.

Through several means of ceramic comparisons (Table 3), the four Saline Creek sites can be readily sorted into two groups: Group I, the Alligator Pond site, with a very high plain to decorated sherd ratio (P/ DR), little brushed pottery (at least in comparison to the other three sites), considerable wet paste utility ware ceramic sherds, and a relatively low use of bone as a temper; and Group II, the other three sites. The Group II sites have moderate P/DR values (2.61-2.99), considerable percentages of brushed decorated sherds among all the decorated sherds (37.0-55.2\%), lower frequencies (34.5-52.2\%) of wet paste utility wares, and the use of bone temper was moderate at two of the three Group II sites, but very low at the other.

Table 3. Selected ceramic comparisons between the Saline Creek sites.

\begin{tabular}{llllll}
\hline Sites & $\begin{array}{l}\text { Plain/Decorated } \\
\text { Sherd Ratio }\end{array}$ & $\%$ Brushed* & $\begin{array}{l}\text { Wet } \\
\text { Paste } \%\end{array}$ & $\begin{array}{l}\text { \% Bone- } \\
\text { Tempered }\end{array}$ & $\mathrm{N}$ \\
\hline $\begin{array}{l}\text { Group I } \\
\text { 41SM442 }\end{array}$ & 5.89 & 10.1 & 59.9 & 6.9 & $2440+$ \\
Group II & & & & & \\
41SM440 & 2.99 & 43.5 & 47.8 & 13.8 & 275 \\
41SM444 & 2.77 & 55.2 & 34.5 & 5.0 & 83 \\
41SM441 & 2.61 & 37.0 & 52.2 & 24.0 & 83 \\
\hline
\end{tabular}

*percent brushed among all decorated sherds from the site; ** percent wet paste (i.e., incised, punctated, appliqued, incised-punctated, etc.) among all decorated sherds from the site + does not include 13 Woodland period sandy paste sherds (i.e., Goose Creek Plain, var. unspecified)

P/DR values from numerous Caddo sites in East Texas appear to hold considerable promise as an independent means of establishing the age of Caddo ceramic-bearing components (provided samples of plain and decorated sherds are larger than about 200-300 sherds per site, which three of the four sites on Saline Creek meet. Thus, the P/DR comparisons for these assemblages still prove useful in helping to sort early from later Caddo occupations. When P/DR ratios from a number of different ceramic assemblages from the various ceramic traditions/regions in East Texas are linked with absolute ages as established by radiocarbon dating from those assemblages (see Selden and Perttula 2013), it is expected that further refinements in how $\mathrm{P} / \mathrm{DR}$ ratios change through time in East Texas Caddo sites will be established. At the moment, looking at Early Caddo to Historic Caddo ceramic assemblages in the region through time, the trend is that ceramic assemblages have lower proportions of undecorated sherds through time and thus a lower P/DR ratio (Perttula 2008:9, 315-317). Analyzed pre-A.D. 1200 sites in East Texas have plain/decorated sherd ratios that appear to range from 2.97 to greater than 4.80; the Alligator Pond site P/DR of 5.80 would seem to fit this pre-A.D. 1200 P/DR range (see Table 9). Middle Caddo sites (ca. A.D. 1200-1450) have ratios that range between 1.30-2.65; the other Saline Creek sites generally fall in the Middle Caddo period based on their P/ DR (see Table 3), but not on the basis of the proportion of brushed sherds in their assemblages. In known Late Caddo sites in the Neches, Angelina, and Sabine river basins, by contrast, the P/DR ranges from only 1.30-0.47, much different than the Saline Creek Caddo sites. Finally, post-A.D. 1680 Caddo occupations in the Neches-Angelina river basin have P/DR ratios that range from 0.20-0.30.

Further chronological confirmation of the ages of the four Caddo components is reflected in the percentages of brushed pottery in each assemblage (see Table 3). At the earlier Alligator Pond site, only 10.1\% of the decorated sherds are brushed, compared to between 37.0-55.2\% in the three other Saline Creek sites. It has been shown repeatedly in Caddo ceramic studies in East Texas that the proportion of brushed sherds in decorated sherd assemblages steadily increases through time, beginning around ca. A.D. 1200. By the 
early $15^{\text {th }}$ century A.D., in particular, Caddo potters in the upper Neches River basin and parts of the upper Sabine River basin began to manufacture considerable numbers of jars with brushed vessel bodies and rims (Perttula 2011). Given the relatively high proportion of brushed sherds in three of the Saline Creek sites, their ceramic assemblage P/DR values, and the occurrence of several Poynor Engraved sherds at the Sarah's Deer Stand (41SM440) and Thacker Farm House (41SM444) sites, it seems likely that they were occupied beginning about the latter part of the $14^{\text {th }}$ century through the mid- $15^{\text {th }}$ century A.D., and were probably abandoned after that time. The low percentage of brushed sherds, in concert with the high P/DR values, at the Alligator Pond site are primarily consistent with a pre-A.D. 1200 Caddo occupation, or at least an occupation that may have ended by around that time. The high proportions of red-slipped sherds is especially notable among the fine wares from this site.

The pre-1860 occupations at the Sarah's Deer Stand and Alligator Pond sites are also notable; certain historic artifacts (i.e., glass beads, a honey-colored French gunflint, and possible hand-painted pearlware rim and body sherds) at the Alligator Pond site hint at an early use of this part of the Saline Creek valley by ca. 1830. It is probable that these artifacts are associated with an early Anglo-American settlement of the region, but if there is a pre-1830 occupation preserved at the Alligator Pond site, it may mark a briefly occupied habitation site by a Native American group such as the Caddo, whose traditional homelands these were, or the Cherokee, who had immigrated to the area by 1820 (Everett 1990). Since known Native American sites dating to the early $19^{\text {th }}$ century are very rare in East Texas, one focus of further investigations at the Alligator Pond site would be to more fully ascertain the age, cultural affiliation, and context of the 19th century components at the site.

\section{ACKNOWLEDGEMENTS}

We would like to thank Lance Trask for the photographic images of the artifacts illustrated in this article.

\section{REFERENCES CITED}

Aten, L. E. and C. N. Bollich

2011 Early Ceramic Sites of the Sabine Lake Area, Coastal Texas and Louisiana. Studies in Archeology 43. Texas Archeological Research Laboratory, The University of Texas at Austin.

Diggs Jr., G. M., B. L. Lipscomb, M. D. Reed and R. J. O'Kennon

2006 Illustrated Flora of East Texas, Volume One: Introduction, Pteridophytes, Gymnosperms, and Monocotyledons. Sida, Botanical Miscellany, No. 26. Botanical Research Institute of Texas, Fort Worth.

Everett, D.

1990 The Texas Cherokees: A People Between two Fires, 1819-1840. University of Oklahoma Press, Norman.

Hatherly, D. T.

1993 Soil Survey of Smith County, Texas. United States Department of Agriculture, Soil Conservation Service, in cooperation with the Texas Agricultural Experiment Station and the Texas State Soil and Water Conservation Board, Washington, D.C.

Perttula, T. K.

2011 The Ceramic Artifacts from the Lang Pasture Site (41AN38) and the Place of the Site within an Upper Neches River Basin Caddo Ceramic Tradition. In Archeological Investigations at the Lang Pasture Site (41AN38) in the Upper Neches River Basin of East Texas, assembled and edited by T. K. Perttula, D. B. Kelley, and R. A. Ricklis, pp. 145-320. Archeological Studies Program Report No. 129, Texas Department of Transportation, Environmental Affairs Division, Austin. 
Perttula, T. K. (editor)

2008 Lake Naconiche Archeology, Nacogdoches County, Texas: Results of the Data Recovery Excavations at Five Prehistoric Archeological Sites. 2 Vols. Report of Investigations No. 60. Archeological \& Environmental Consultants, LLC, Austin.

Perttula, T. K. and M. Walters

2012 Caddo Sites in the Saline Creek Basin in Northern Smith County, Texas. Journal of Northeast Texas Archaeology 36:47-63.

Samford, P. M.

2000 Response to a Market: Dating English Underglaze Transfer-Printed Wares. In Approaches to Material Culture Research for Historical Archaeologists, compiled by D. R. Brauner, pp. 56-85. $2^{\text {nd }}$ Edition. The Society for Historical Archaeology, California, Pennsylvania.

Schambach, F. F.

1982 An Outline of Fourche Maline Culture in Southwest Arkansas. In Arkansas Archeology in Review, edited by N. L. Trubowitz and M. D. Jeter, pp. 132-197. Research Series No. 15. Arkansas Archeological Survey, Fayetteville.

Selden, R. Z., Jr. and T. K. Perttula

2013 Radiocarbon Trends and the East Texas Caddo Tradition (ca. A.D. 800-1680). Southeastern Archaeology 32(1):85-96.

Story, D. A.

2000 Introduction. In The George C. Davis Site, Cherokee County, Texas, by H. P. Newell and A. D. Krieger, pp. 1-31.2nd Edition. Society for American Archaeology, Washington, D.C.

Story, D. A. (editor)

1995 The Deshazo Site, Nacogdoches County, Texas, Vol. 2: Artifacts of Native Manufacture. Studies in Archeology 21. Texas Archeological Research Laboratory, The University of Texas at Austin.

Suhm, D. A., and E. B. Jelks (editors)

1962 Handbook of Texas Archeology: Type Descriptions. Special Publication No. 1, Texas Archeological Society, and Bulletin No. 4, Texas Memorial Museum, Austin. Reprinted in 2009, Gustav's Library, davenport, Iowa.

Turner, E. S. and T. R. Hester

1999 A Field Guide to Stone Artifacts of Texas Indians. Gulf Publishing, an imprint of Rowman \& Littlefield Publishers, Inc., Lanham, Maryland. 